\title{
Influence of Dopamine on Precursor Cell Proliferation and Differentiation in the Embryonic Mouse Telencephalon
}

\author{
Margherita Popolo Deirdre M. McCarthy Pradeep G. Bhide \\ Department of Neurology, Massachusetts General Hospital, Harvard Medical School, Boston, Mass., USA
}

\section{Key Words}

Ganglionic eminence - Dopamine - Cell cycle · Striatum •

Prefrontal cortex $\cdot D_{1}$ receptor $\cdot D_{2}$ receptor

\begin{abstract}
Dopamine and its receptor binding sites appear in the brain early in the embryonic period raising the possibility that dopamine may influence brain development. We show that one component of dopamine's role in brain development is its ability to influence proliferation and differentiation of progenitor cells in the neostriatum and the dorsomedial prefrontal cortex on embryonic day 15 in mice. Dopamine and a $\mathrm{D}_{1}$-like receptor agonist reduce the relative proportion of progenitor cells incorporating the $S$ phase marker bromodeoxyuridine. $A D_{2}$-like agonist produces the opposite effect. Both the effects are evident in the lateral ganglionic eminence, neuroepithelial precursor of the neostriatum and in the neuroepithelium of the dorsomedial prefrontal cortex. Neostriatal progenitor cells are more responsive than cortical progenitor cells to the effects of dopamine receptor activation. Furthermore, progenitor cells in the ventricular zone are more responsive to $D_{1}$-like agonists and progenitors in the subventricular zone more so to $D_{2}$-like agonists.
\end{abstract}

\section{KARGER}

Fax +4161306 1234

E-Mail karger@karger.ch

www. karger.com (c) 2004 S. Karger AG, Basel

Accessible online at: www. karger.com/dne
Thus, dopamine's developmental effects show regional and progenitor cell type specificity, presumably due to heterogeneity in the distribution of its receptor binding sites.

Copyright $\odot 2004$ S. Karger AG, Basel

\section{Introduction}

Dopamine is a neurotransmitter involved in the regulation of mood, motivation and motor function in the mature brain. Dopamine and its receptor binding sites are present in the embryonic brain early in development, prior to the onset of synaptogenesis [Jung and Bennett, 1996; Diaz et al., 1997; Shearman et al., 1997; Ohtani et al., 2003]. Therefore, a role for dopamine in brain development that is independent of its role at the synapse in the mature brain appears likely [Lauder, 1988, 1993; Levitt et al., 1997; Nguyen et al., 2001]. One component of dopamine's developmental role is its ability to modulate the cell cycle of progenitor cells in dopamine-rich areas of the embryonic brain such as the neostriatum [Ohtani et al., 2003]. Dopamine is one of many neurotransmitters that can influence progenitor cell proliferation in the brain [LoTurco et al., 1995; Lavdas et al., 1997; Haydar et al.,

Dr. Pradeep G. Bhide

Developmental Neurobiology, Massachusetts General Hospital

149,13 th Street

Charlestown, MA 02129 (USA)

Tel. +1 617726 5763, Fax +1617 726 6656, E-Mail Bhide@helix.mgh.harvard.edu 
2000; Popovik and Haynes, 2000; Demarque et al., 2002; Luk et al., 2003]. In the present study, we illustrate a potential role for dopamine and its receptors in the regulation of progenitor cell proliferation and differentiation in two regions of the embryonic telencephalon, namely the neostriatum and the cerebral cortex.

Neurons of the neostriatum are produced in the lateral ganglionic eminence (LGE), a transient neuroepithelial structure bordering the embryonic lateral ventricles in the basal telencephalon [Deacon et al., 1994; Nery et al., 2002; Stenman et al., 2003]. Neurons of the cerebral cortex arise from the cortical neuroepithelium (mostly projection neurons) and the ganglionic eminence of the basal telencephalon (interneurons) [Anderson et al., 1997; Lavdas et al., 1999; Marin et al., 2000; Wichterle et al., 2001]. Our previous experiments showed that dopamine receptor activation modulated the cell cycle of LGE progenitors [Ohtani et al., 2003]. In the present study, we extend those findings and show that dopamine receptor activation influences progenitor cell proliferation in the LGE as well as the neuroepithelium of the dorsomedial prefrontal cortex (PFC) and differentiation of neostriatal progenitor cells.

\section{Materials and Methods}

\section{Animals}

We used timed pregnant CD1 mice (Charles River Laboratories, Wilmington, Mass., USA) housed in our institutional animal facility. The day of vaginal plug discovery (confirming insemination) was designated embryonic day 0 (E0). Our experiments utilized E15 mice. All of the experimental procedures were in full compliance with institutional guidelines and the NIH Guide for the Care and Use of Laboratory Animals. Although we received timed pregnant mice from the vendor, we ascertained the age of each embryo by examination of the external morphological features [Theiler, 1972; Kaufman, 1992]. Embryos or entire litters that did not fulfill the criteria for E15 were discarded.

\section{Tyrosine Hydroxylase Immunohistochemistry}

Timed pregnant dams were anesthetized (ketamine, $50 \mathrm{mg} / \mathrm{kg}$ body weight, and xylazine, $10 \mathrm{mg} / \mathrm{kg}$ body weight, i.p.); embryos were removed and immediately decapitated. The embryonic heads were fixed by immersion in 4\% paraformaldehyde in $0.1 \mathrm{M}$ phosphate buffer. Brains were removed from the heads, immersed in the fixative and stored at $4^{\circ} \mathrm{C}$ for $18-24 \mathrm{~h}$. The brains were sectioned in the coronal or sagittal plane on a Vibratome at a thickness of $60 \mu \mathrm{m}$. Tyrosine hydroxylase (TH) immunohistochemistry was performed on the Vibratome sections using a rabbit polyclonal antiserum (Chemicon, Temecula, Calif., USA; diluted 1:100), Vector Elite peroxidase kit (Vector Laboratories, Burlingame, Calif., USA) and diaminobenzidine as the chromogen. Following the immunohistochemistry, the sections were mounted on glass slides (SuperFrost plus, Fisher Scientific, Fairlawn, N.J., USA), dehydrated in ethanol, cleared in xylene and coverslipped with Permount. We used 3-4 embryos from each of 2 litters.

\section{Bromodeoxyuridine and TH Double Immunohistochemistry}

Pregnant dams carrying E15 mice were administered 3 bromodeoxyuridine (BrdU) injections (Sigma Chemical Co., St. Louis, Mo., USA; $50 \mu \mathrm{g} / \mathrm{g}$ body weight, i.p.) at 3-hour intervals beginning at 9 a.m. The 3-hour interval was chosen because BrdU administered to the mother is available for uptake in the fetal brain for at least $3 \mathrm{~h}$ [Takahashi et al., 1992; Hayes and Nowakowski, 2000]. The mothers were anesthetized, and the embryos were removed and decapitated $0.5 \mathrm{~h}$ after the final BrdU injection. BrdU reaches saturating concentrations in fetal brains by $0.5 \mathrm{~h}$ after its administration to the mother [Takahashi et al., 1992; Hayes and Nowakowski, 2000]. Thus, the embryos were exposed to BrdU for a total of $6.5 \mathrm{~h}$. Three injections with a 6.5-hour labeling interval were chosen to label a higher proportion of precursor cells than would have been possible with shorter labeling intervals using only 1 or 2 injections. The embryonic heads were fixed by immersion in $4 \%$ paraformaldehyde in $0.1 \mathrm{M}$ phosphate buffer. The brains were removed from the heads and stored in the same fixative at $4^{\circ} \mathrm{C}$ for $18-24 \mathrm{~h}$. Vibratome sections of the brains were cut at a thickness of $60 \mu \mathrm{m}$, as described above. Doublelabeling immunohistochemistry for $\mathrm{BrdU}$ and $\mathrm{TH}$ was performed using the polyclonal TH antibody, a monoclonal anti-BrdU antibody (Becton-Dickinson, Mountain View, Calif., USA; 1:75 dilution) and fluorescent secondary antibodies (Cy3-conjugated donkey antirabbit IgG and Cy2-conjugated donkey antimouse IgG; Jackson Immunoresearch, Westgrove, Pa., USA). The sections were mounted on glass slides and coverslipped using a water-soluble mounting medium. The sections were examined in a Zeiss LSM laser confocal microscope. We used 3-4 embryos from each of 2 litters for this experiment.

\section{In vivo Administration of Dopamine $D_{1}$-Like Receptor Agonist}

We administered 2 injections of the $\mathrm{D}_{1}$-like receptor agonist SKF 81297 (RBI/Sigma, $10 \mathrm{mg} / \mathrm{kg}$ or $20 \mathrm{mg} / \mathrm{kg}$ i.p.) or saline (control) to pregnant mice carrying E15 embryos. The injections were spaced $3 \mathrm{~h}$ apart. BrdU (50 mg/kg i.p.) was administered $1 \mathrm{~h}$ after the second SKF 81297 injection. The mother was anesthetized $2 \mathrm{~h}$ after the BrdU injection, and the embryos were removed, decapitated and the embryonic heads were immersed in $70 \%$ ethanol. Thus, the embryos were exposed to SKF 81297 for a total of $6 \mathrm{~h}$ and to BrdU for the final $2 \mathrm{~h}$. The brains were removed from the heads and stored in $70 \%$ ethanol at room temperature for 18-24 $\mathrm{h}$ and then embedded in paraffin wax. We used 3 litters per dose of SKF 81297 and 3 litters in the control (saline) group.

\section{Administration of Dopamine or the $D_{1}$-Like Receptor Antagonist} Schering 23390 to the Embryonic Brain in utero

Timed pregnant mice were anesthetized as described above, and a laparotomy was performed to expose the gravid uterine horns. The orientation of the embryonic heads inside the intact amniotic sacs was established without incising the uterine wall. The anatomical landmarks on the dorsal surface of the embryonic head were identified and $1 \mu 1$ solution of Schering 23390 (RBI/Sigma; $100 \mu M$ in PBS, an estimated maximum final concentration of $10 \mu M$, assuming a ventricular volume of 10-20 $\mu \mathrm{l}$ and diffusion of the drug into the brain) or PBS (control) was injected into the left cerebral hemisphere using a Hamilton syringe fitted with a glass electrode tip. The injection was targeted approximately to the midpoint along the longitudinal midline. In separate experiments, $1 \mu l$ solution of dopamine (Sig- 
ma; $50 \mu M$ in PBS containing $0.025 \%$ ascorbic acid; an estimated maximum final concentration of $5 \mu M$, assuming a ventricular volume of 10-20 $\mu \mathrm{l}$ and diffusion of the drug into the brain) or $0.025 \%$ ascorbic acid (in PBS) was injected. Ascorbic acid, a potent antioxidant, retards oxidation of dopamine [Marien et al., 1984; Porter et al., 1999]. The injection solutions contained $0.025 \%$ fast green to facilitate visual identification of the injection site in the brain. In every successful injection, the fast green filled the lateral ventricles, and the injected ventricles turned dark green (fig. 1A, B). Failed injections were represented by no dye in the brain, partial filling of the ventricles or the entire hemisphere turning dark green. Every embryo in which the anatomical landmarks could be established unequivocally was injected (usually $2-6$ per mother). Only those embryos in which the injection site could be verified by visual inspection of the green color in the ventricles were used for further analyses. Identification of the embryos was accomplished by noting the location of each embryo, injected successfully or not, along the ovariancervical axis of each uterine horn. Once the injections were completed, the abdominal incision was closed, and the mother recovered from the effects of anesthesia. BrdU was injected to the mother $2 \mathrm{~h}$ after the completion of the last intraventricular injection. The mother was anesthetized again $2 \mathrm{~h}$ after the BrdU injection, and the embryos were removed, decapitated and the heads were immersed in $70 \%$ ethanol. Thus, the embryos were exposed to Schering 23390 or dopamine for $4 \mathrm{~h}$ and to BrdU for the final $2.0 \mathrm{~h}$. The brains were removed from the heads and stored in $70 \%$ ethanol at room temperature for 18-24 $\mathrm{h}$ and then embedded in paraffin wax. We used 5 litters for the Schering 23390 or dopamine injections and 4 litters for saline or ascorbic acid injections.

\section{Calculation of the BrdU Labeling Index}

Effects of dopamine, the $\mathrm{D}_{1}$-like receptor agonist and antagonist on progenitor cell proliferation in vivo were assessed by comparing the BrdU labeling index (LI) in the LGE and the proliferative zones of the PFC. The paraffin-embedded brains were sectioned in the coronal plane at a thickness of $4 \mu \mathrm{m}$ on a rotary microtome. The sections were mounted on glass slides, deparaffinized, processed for BrdU immunohistochemistry and stained with $0.1 \%$ basic fuchsin according to a protocol described previously [Takahashi et al., 1992; Bhide, 1996; Ohtani et al., 2003]. Examples of the histological preparations are shown in figure 1. The BrdU-labeled nuclei appear black, due to cobalt and nickel intensification of the diaminobenzidine reaction product, and the unlabeled nuclei appear reddish pink due to the basic fuchsin stain (fig. 1C-E). The BrdU-labeled and unlabeled nuclei were counted within a $120 \times 240 \mu \mathrm{m}$ sector of the LGE and a $100 \times 100 \mu \mathrm{m}$ sector of the proliferative region of the PFC (fig. 1D, E). The LGE sector was divided into 20 bins (each bin was $120 \times 112 \mu \mathrm{m}$; fig. $1 \mathrm{E}$ ) and the PFC sector into 10 bins (each bin was $10 \times 10 \mu \mathrm{m}$; fig. 1D). The sectors were superimposed on the sections such that bin 1 was at the ventricular surface, with the long axis of the bin aligned with the ventricular border (fig. 1D, E) [Bhide, 1996; Ohtani et al., 2003; Crandall et al., 2004]. The sizes of the LGE and PFC sectors and bins, although different from each other, were similar to those used in our previous studies [Ohtani et al., 2003; Crandall et al., 2004]. The BrdU LI was calculated separately for each bin by dividing the BrdU-labeled cells by the total number of cells. Our previous work showed that both the LGE and the proliferative zones of the PFC can be divided into ventricular and subventricular zones (VZ and SVZ) based on the location of the BrdU-labeled nuclei with respect to the lateral ventricular border in a 2.0 -hour labeling paradigm [Bhide, 1996; Ohtani et al., 2003; Crandall et al., 2004]. Based on those previous data, the BrdU-labeled nuclei located in the 8 bins closest to the ventricular border (i.e. within $96 \mu \mathrm{m}$ from the border) were assigned to the VZ and the remaining nuclei (in bins 9-20) to the SVZ in the LGE. BrdU-labeled nuclei in the 7 bins closest to the ventricular border (i.e. within $70 \mu \mathrm{m}$ from the border) were assigned to the $\mathrm{VZ}$ and the remaining nuclei (in bins 8-10) to the SVZ in the PFC. The BrdU LI was calculated separately for the VZ and the SVZ. We recognize that this method provides us with an approximation of the BrdU LI in the VZ and the SVZ. An accurate measurement would require partitioning the two zones based on detailed analyses of the relative numbers of $S, G_{2}$ and $M$ phase nuclei [Takahashi et al., 1994; Sheth and Bhide, 1997] and/or mitotic figures in the VZ and the SVZ following single and/or multiple exposures to BrdU [Bhide, 1996; Cai et al., 1997]. Such analyses are beyond the scope of this study.

We analyzed 3 embryos obtained from each litter in each treatment group. As mentioned earlier, we used 3-5 litters for each treatment condition. We analyzed 4 sections from each embryo for each of the two brain regions. Preliminary analyses showed that this sampling procedure produced standard error of the mean (SEM) values that were smaller than $10 \%$ of the mean value for a given experimental group. Increasing the number of sections from 4 to 6 per brain or increasing the number of brains from 3 to 4 per litter did not reduce the SEM values further. Differences in BrdU LI between the different groups were analyzed by $t$ test.

\section{Effects of Dopamine and Its Receptor Agonists on Cell}

Proliferation and Differentiation in Dissociated Cell Cultures

Dams carrying E15 mice were anesthetized, the embryos were removed, decapitated and the brains were dissected in culture medium (see below). Basal forebrain samples containing neostriatal differentiating fields as well as the LGE, medial and caudal ganglionic eminences were dissected from the overlying cerebral wall and incubated with $2.5 \%$ trypsin at $37^{\circ} \mathrm{C}$ for $20 \mathrm{~min}$. The samples were washed with culture medium, the cells gently dissociated using a sterile plastic pipette and passed through a $40-\mu \mathrm{m}$ cell strainer and resuspended in DMEM/F $/ 2$ (Gibco BRL, Grand Island, N.Y., USA) containing $2 \mathrm{~m} M L$-glutamine, $0.1 \mathrm{~g} / 1$ penicillin/streptomycin and $10 \%$ fetal bovine serum (heat-inactivated at $55^{\circ} \mathrm{C}$ for $30 \mathrm{~min}$ ). The cells were plated on 22-mm polylysine/laminin-coated coverslips (BD Bioscience/Clontech, San Jose, Calif., USA) at a density of 300,000 cells/well in 24-well plates. Cultures were maintained in a humidified incubator at $37^{\circ} \mathrm{C}$ under $5 \% \mathrm{CO}_{2}$.

Dopamine ( 1 or $5 \mu M)$ plus ascorbic acid $(0.025 \%)$, ascorbic acid alone $(0.025 \%)$, the dopamine $\mathrm{D}_{1}$-like receptor agonist SKF 81297 $(1,10$ or $20 \mu M)$ or the $\mathrm{D}_{2}$-like receptor agonist quinpirole hydrochloride (RBI/Sigma; 1,10 or $20 \mu M$ ) was added to the medium 2$3 \mathrm{~h}$ after plating. In other experiments, the dopamine $\mathrm{D}_{1}$-like receptor antagonist Schering 23390 (RBI/Sigma; $10 \mu M$ ) was added to the culture medium $2-3 \mathrm{~h}$ after plating the cells, and $2 \mathrm{~h}$ later, dopamine plus ascorbic acid or ascorbic acid alone was added. In every type of experiment, $\mathrm{BrdU}(10 \mu M)$ was added to the medium along with the drugs. In all the cases, the medium was discarded $12 \mathrm{~h}$ from the time of addition of the drugs and the BrdU, the cells were washed with fresh medium (without the drugs or the BrdU) and cultured for a further $12 \mathrm{~h}$ in fresh medium (without the drugs or the BrdU). In other experiments, the cells were cultured longer, for a total of 5 days following the initial 12-hour period of exposure to the drugs. In these long-term experiments, half of the medium was changed every 2 


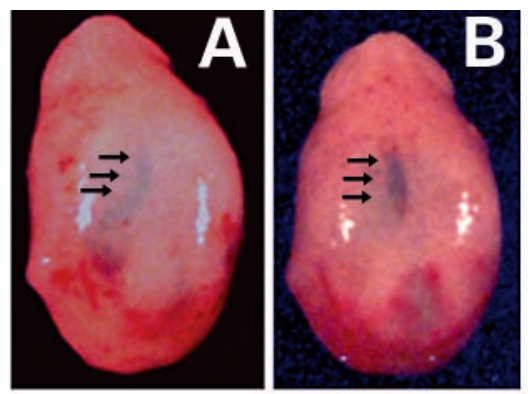

C
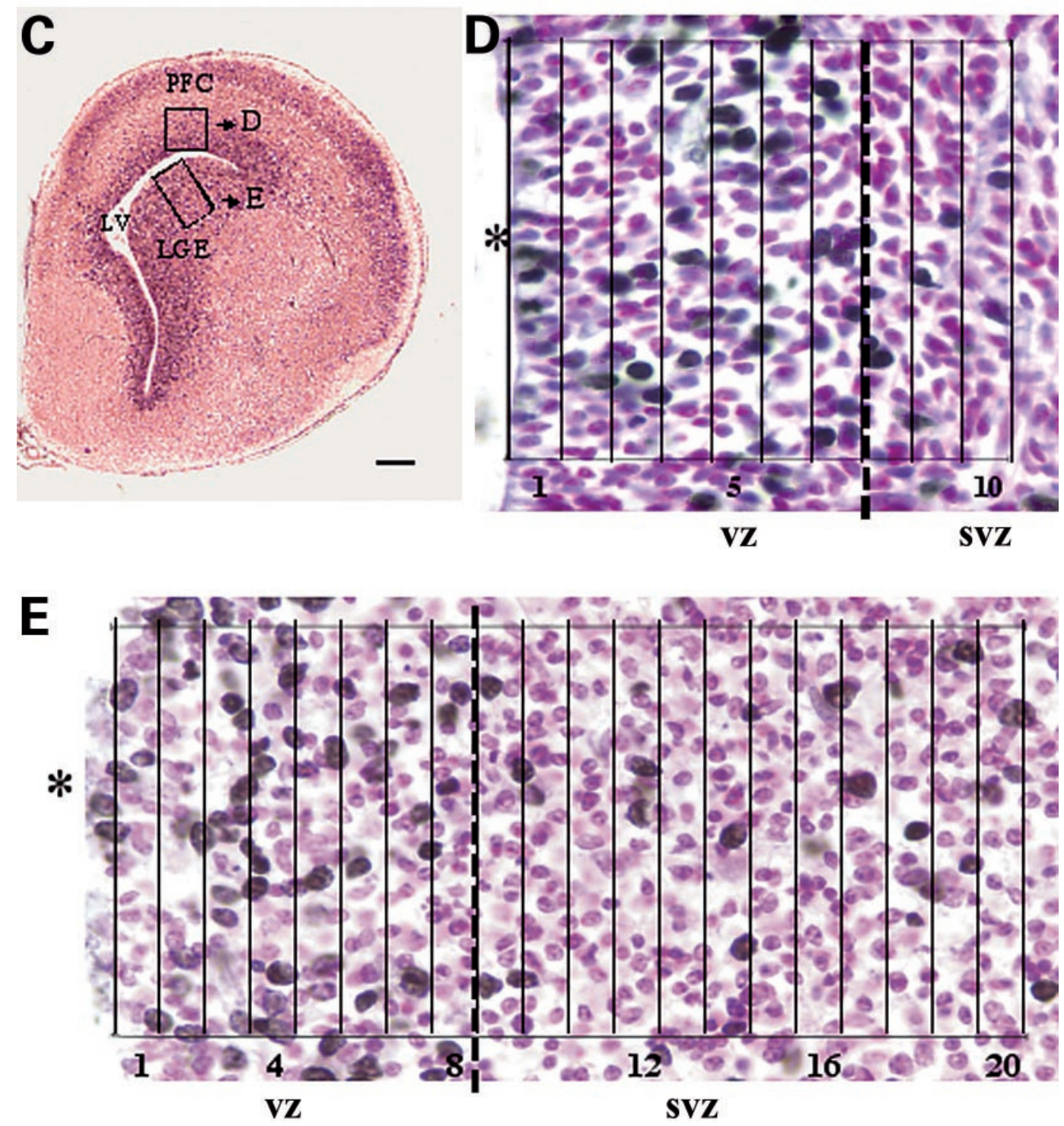
days. At the end of the experiments, in all the cases, the cultures were fixed with $4 \%$ paraformaldehyde in $0.1 M$ phosphate buffer for $15 \mathrm{~min}$. We used the 12-hour drug exposure paradigm, as our previous work showed that $12 \mathrm{~h}$ of exposure to dopaminergic drugs produced significant changes in progenitor cell proliferation in vitro [Ohtani et al., 2003].

\section{Immunocytochemical Labeling of Cultured Cells}

We used the following primary antisera: anti-BrdU (mouse monoclonal, 1:75; Becton-Dickinson, or rat monoclonal 1:100, Immunologicals Direct, Kidlington, UK), antidoublecortin (1:200, goat polyclonal; Santa Cruz Biotechnology, Santa Cruz, Calif., USA), anti-NeuN (1:500, mouse monoclonal; Chemicon), anti-proliferating-cell nuclear antigen (anti-PCNA; 1:100, mouse monoclonal; Santa Cruz Biotechnology), anti-glial-fibrillary-acidic-protein (antiGFAP; 1:500, mouse monoclonal Cy3 conjugated; Sigma) and anti-

Fig. 1. Examples of in utero, intraventricular injections confirmed by visualization of the dye fast green in the lateral ventricles of the injected hemisphere of E15 mouse embryos (A, B). Following the injection, the embryos were removed, decapitated and the heads were photographed to show the label. The skull and the overlying skin are intact. The visibility of the dye depends on the camera angle (A is lighter but shows the entire left ventricle, while $\mathbf{B}$ is darker but shows only the rostral half of the ventricle). C-E Examples of histological sections processed for BrdU immunohistochemistry to illustrate the method of analysis of BrdU labeling index in the LGE and the neuroepithelium of the PFC. LV = Lateral ventricle. BrdU immunohistochemistry was performed on $4-\mu \mathrm{m}$-thick paraffin-embedded sections of E15 brains (C). The sections were stained with basic fuchsin. BrdU-labeled nuclei are black, and the other nuclei are reddish pink (C-E). C is a low-magnification view of a typical histological section through the LGE and the PFC. The boxed areas indicate, approximately, the site of BrdU labeling index analysis in the LGE and the PFC. Each boxed area is enlarged in $\mathbf{D}$ and $\mathbf{E}$, as indicated by the arrows in C. D shows the $100 \times 100 \mu \mathrm{m}$ sector within the neuroepithelium of the PFC in which the BrdU-labeled and unlabeled nuclei were counted and the BrdU labeling index calculated. The sector was further subdivided into 10 'bins' (numbered from 1 to 10). Each bin was $100 \times 10 \mu \mathrm{m}$ in size. The long axis of bin 1 was aligned with the lateral ventricular border (asterisk in D). The BrdU labeling index was calculated for each bin. Based on our previous data, the neuroepithelium was divided into a ventricular zone (VZ) and a subventricular zone (SVZ). As indicated by the dotted line in D, the VZ extended from bin 1 to 7 and the SVZ from bin 8 to 10 . E shows the $120 \times 240 \mu \mathrm{m}$ sector in which the BrdU labeling index was calculated in the LGE. The LGE sector was subdivided into 20 bins (numbered from 1 to 20 ), each of which was $120 \times 12 \mu \mathrm{m}$ in size. The LGE was also divided into a VZ (bins 1-8) and SVZ (bins 9-20), as indicated by the dotted line in $\mathbf{E}$. The long axis of bin 1 was aligned with the lateral ventricular border (asterisk in E). It was difficult to perfectly align bin 1 with the ventricular border of the LGE due to the curvature of the ventricular surface. The asterisks in $\mathbf{D}$ and E indicate the lateral ventricular border. Scale bar in $\mathbf{C}=100 \mu \mathrm{m}$. Each bin in $\mathbf{D}$ and $\mathbf{E}$ is drawn to scale.
A2B5 (1:100, mouse monoclonal; Chemicon). We used Cy2- or Cy3conjugated antimouse, antigoat or antirabbit secondary antibodies diluted 1:200 (Jackson Immunoresearch). All the antibodies were diluted in PBS. Following the immunocytochemistry, the cells were stained for $20 \mathrm{~min}$ in the dark with bisbenzimide (H 33342; Sigma, $4 \mu \mathrm{g} / \mathrm{ml}$ ) to visualize nuclear morphology. The cells were examined under a Nikon E400 fluorescence microscope, and the images were captured using a $\times 40$ objective, a Spot digital camera (RT-Slider; Spot Diagnostic Instruments, Sterling Heights, Mich., USA) and image acquisition and analysis software (Spot RT software v3.5). Five to 6 microscope fields were selected for analysis from each coverslip using a systematic random sampling procedure. Every labeled cell within the field was counted, and the average number of labeled cells per field was calculated. Examples of cultured cells labeled with antibodies against BrdU, A2B5, doublecortin, PCNA and NeuN as well as nuclei labeled with bisbenzimide are shown in figure $2 \mathrm{~F}-\mathrm{I}$.

We used 8-10 embryos from each litter and 2 litters per experiment. Both hemispheres from a given brain were used. All samples from a given litter were pooled prior to dissociation of the cells. Each litter was considered as one experiment. We analyzed 5-6 coverslips from a given treatment condition and averaged the values to obtain a mean value for that experiment. Each experiment (i.e. treatment condition) was repeated at least 4 times. Differences between experimental groups were analyzed by $t$ test.

\section{Results}

\section{TH-Positive Axons Enter the LGE and the Neuroepithelium of the PFC}

Immunohistochemistry for $\mathrm{TH}$ showed that $\mathrm{TH}$-positive axons are present in the basal telencephalon and the cerebral wall on E15 (fig. 2A). The TH staining is remarkably robust in the basal telencephalon, especially in the neostriatal differentiating fields, which contain postmitotic cells, compared to the cerebral wall (fig. 2A, compare STR with $\mathrm{CW}$ ). At low magnification, the $\mathrm{TH}$ staining appeared to localize to the neostriatal differentiating fields (fig. 2A) and to a thin band in the intermediate zone and lower cortical plate of the dorsomedial cerebral wall (STR and asterisk in fig. 2A). However, higher magnification showed that some TH-positive axons, especially axonal growing tips, entered the neuroepithelial regions in both the basal telencephalon and the dorsomedial cerebral wall (fig. 2B, C). When BrdU and TH double labeling was performed, $\mathrm{TH}$-positive presumptive axonal growing tips were found intermingled with BrdU-positive cells both in the LGE and the PFC (fig. 2D, E). In an earlier study, we found that dopamine is present in the basal forebrain of embryonic mice as early as E13, coincident with the appearance of $\mathrm{TH}$-positive axons in that region [Ohtani et al., 2003]. 
Fig. 2. $\mathrm{TH}$ and BrdU immunohistochemistry in $60-\mu \mathrm{m}$-thick Vibratome sections of the E15 brain (A-E). A Bright-field view of a section processed for TH immunohistochemistry using diaminobenzidine as the chromogen. TH-positive profiles appear dark brown or black. TH labeling is robust in the basal telencephalon, especially in the striatal differentiating fields (STR in A). A thin band of TH-labeled fibers is visible also in the dorsal and medial cerebral wall (asterisk; CW). However, THpositive profiles are not visible in the LGE or the neuroepithelium of the cerebral wall immediately adjacent to the lateral ventricle (LV) at this magnification. The black arrows point to background staining at the edges of the section. A higher-magnification view of sections processed for $\mathrm{BrdU}$ and TH double immunohistochemistry (B-E) and examined in a confocal microscope revealed that $\mathrm{TH}-$ positive axons (red) are not only concentrated in the striatal differentiating fields (STR in B) and cortical plate (CP) and intermediate zone (IZ) of the cerebral wall $(\mathbf{C})$, but that some TH-positive axons enter the neuroepithelium and are in close proximity to BrdU-labeled precursor cells (green) in the LGE (arrow in D) and the cerebral wall (arrow in E). The white arrow in $\mathbf{C}$ points to background staining at the pial surface at the edge of the section. Immunohistochemical labeling of dissociated neostriatal cells for doublecortin (red, F), BrdU (green, arrow in F), A2B5 (green, G), PCNA (green, arrow in $\mathbf{H}$ ) and NeuN (red in I). A2B5 and doublecortin antibodies label cytoplasm and processes whereas BrdU, PCNA and NeuN antibodies label nuclei. Nuclei in $\mathbf{G}$ and $\mathbf{H}$ are labeled also with bisbenzimide (blue). Cells in $\mathbf{F}, \mathbf{G}$ and $\mathbf{H}$ are from 24-hour cultures and those in I from a 5-day culture. Scale bars in $\mathbf{A}=500 \mu \mathrm{m}$, in $\mathbf{B}=600 \mu \mathrm{m}$, in $\mathbf{C}$, $\mathbf{D}=15 \mu \mathrm{m}$, in $\mathbf{E}, \mathbf{F}=10 \mu \mathrm{m}$, in $\mathbf{G}, \mathbf{H}=15 \mu \mathrm{m}$ and in $\mathbf{I}=10 \mu \mathrm{m}$.

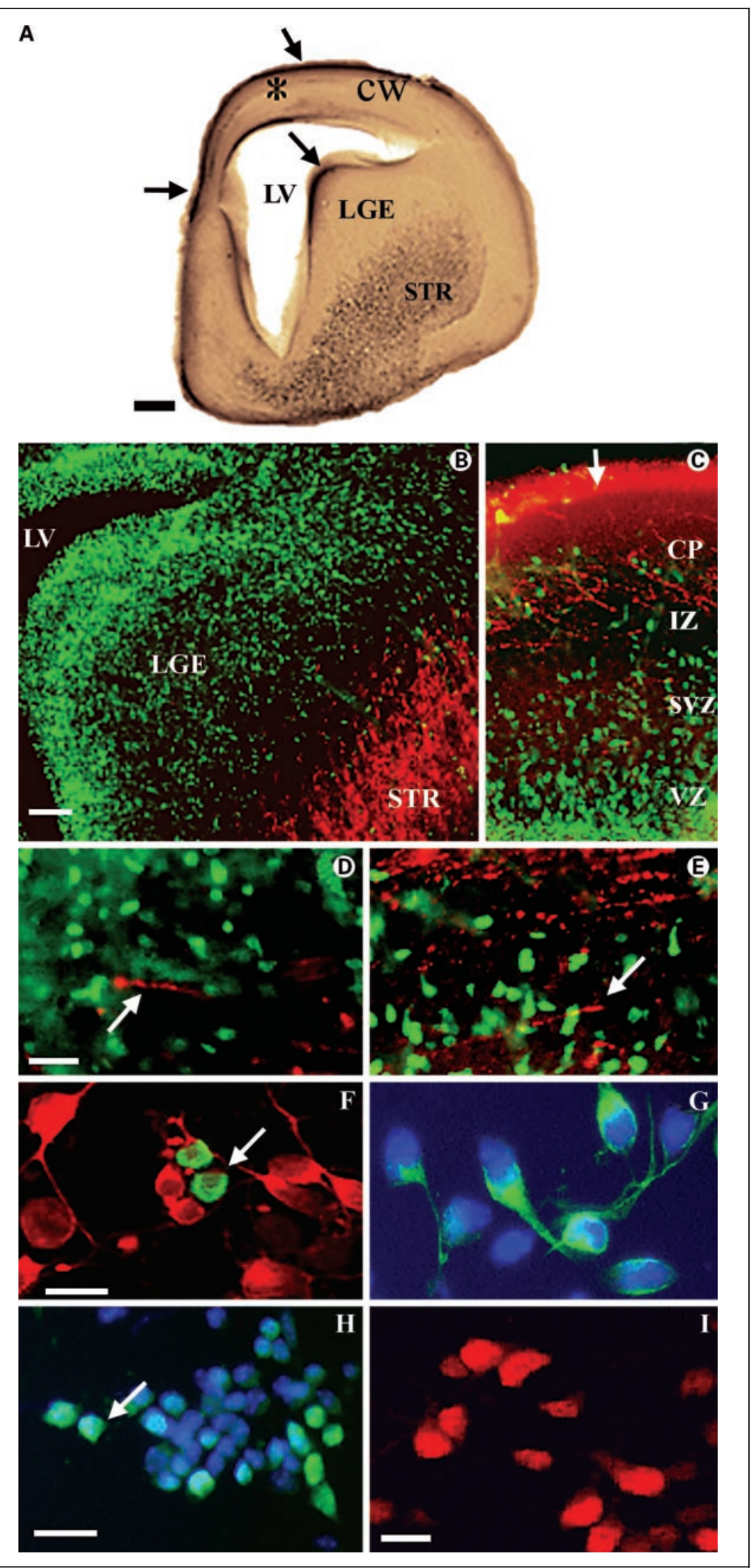

Popolo/McCarthy/Bhide 

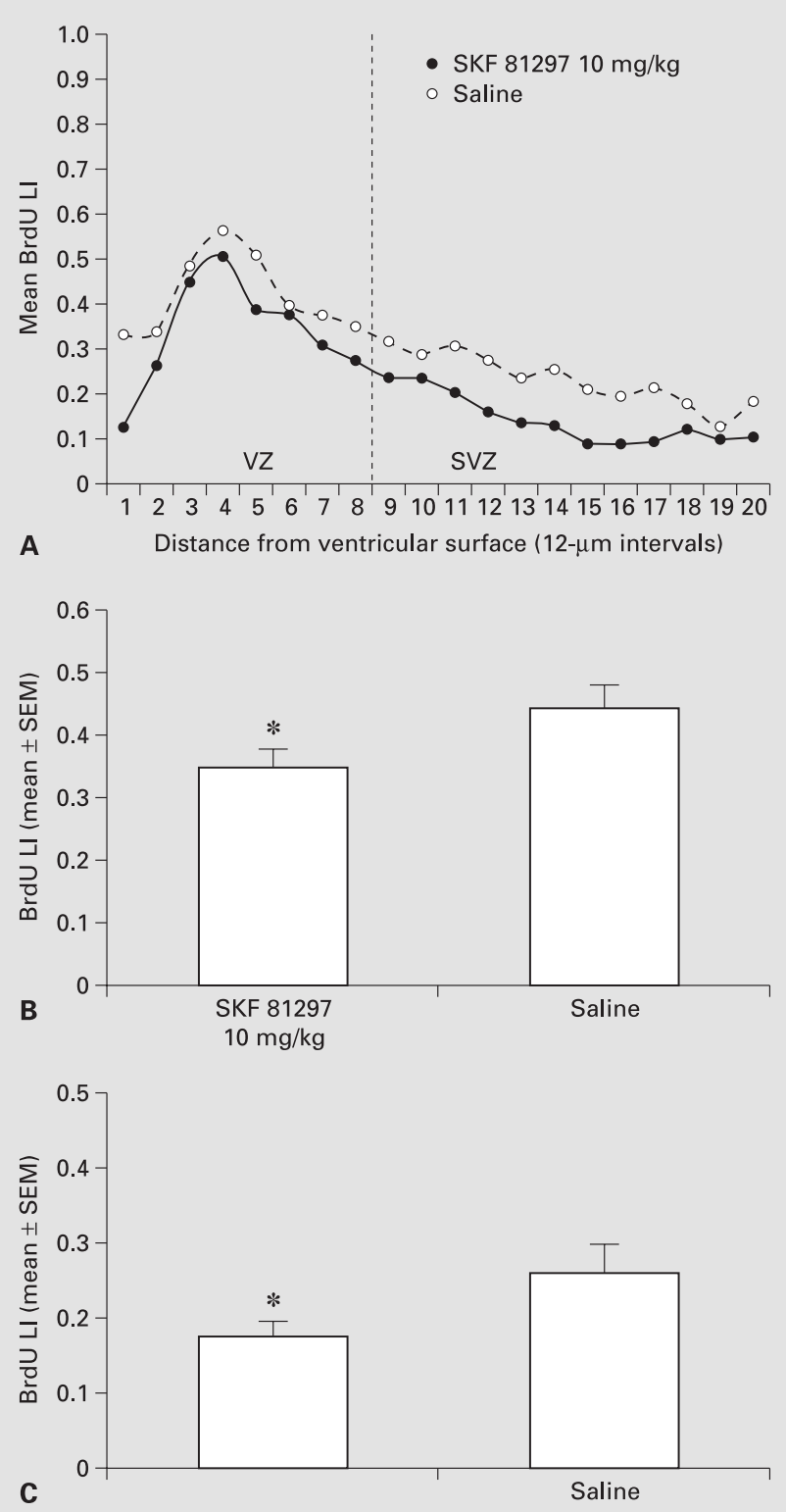

3

Fig. 3. Effects of intraperitoneal administration of the $D_{1}$-like receptor agonist SKF 81297 on the 2.0-hour BrdU LI in the LGE. Initially, the LI was calculated and plotted for each of the 20 'bins' (each bin was $12 \times 120 \mu \mathrm{m}$ in size) within a $120 \times 240 \mu \mathrm{m}$ sector of the LGE (A). This analysis shows that the interkinetic nuclear migratory pattern, a characteristic feature of pseudostratified ventricular epithelia such as that in the VZ, is preserved following the administration of the $\mathrm{D}_{1}$-like agonist. Thus, the highest LI was in bins 3-7, which is the $\mathrm{S}$ phase zone. The LI is lower in the SKF-81297-injected group compared to the saline group in every bin. The LGE was partitioned into a VZ and SVZ, respectively, and the LI was calculated separately for the two zones. The LI was decreased in the SKF 81297 group in the $\operatorname{VZ}(\mathbf{B})$ and the $\operatorname{SVZ}(\mathbf{C}) .{ }^{*} \mathrm{p}<0.05$

Fig. 4. Effects of intraperitoneal administration of the $D_{1}$-like receptor agonist SKF 81297 (10 or $20 \mathrm{mg} / \mathrm{kg}$ ) on the 2.0 -hour BrdU LI in
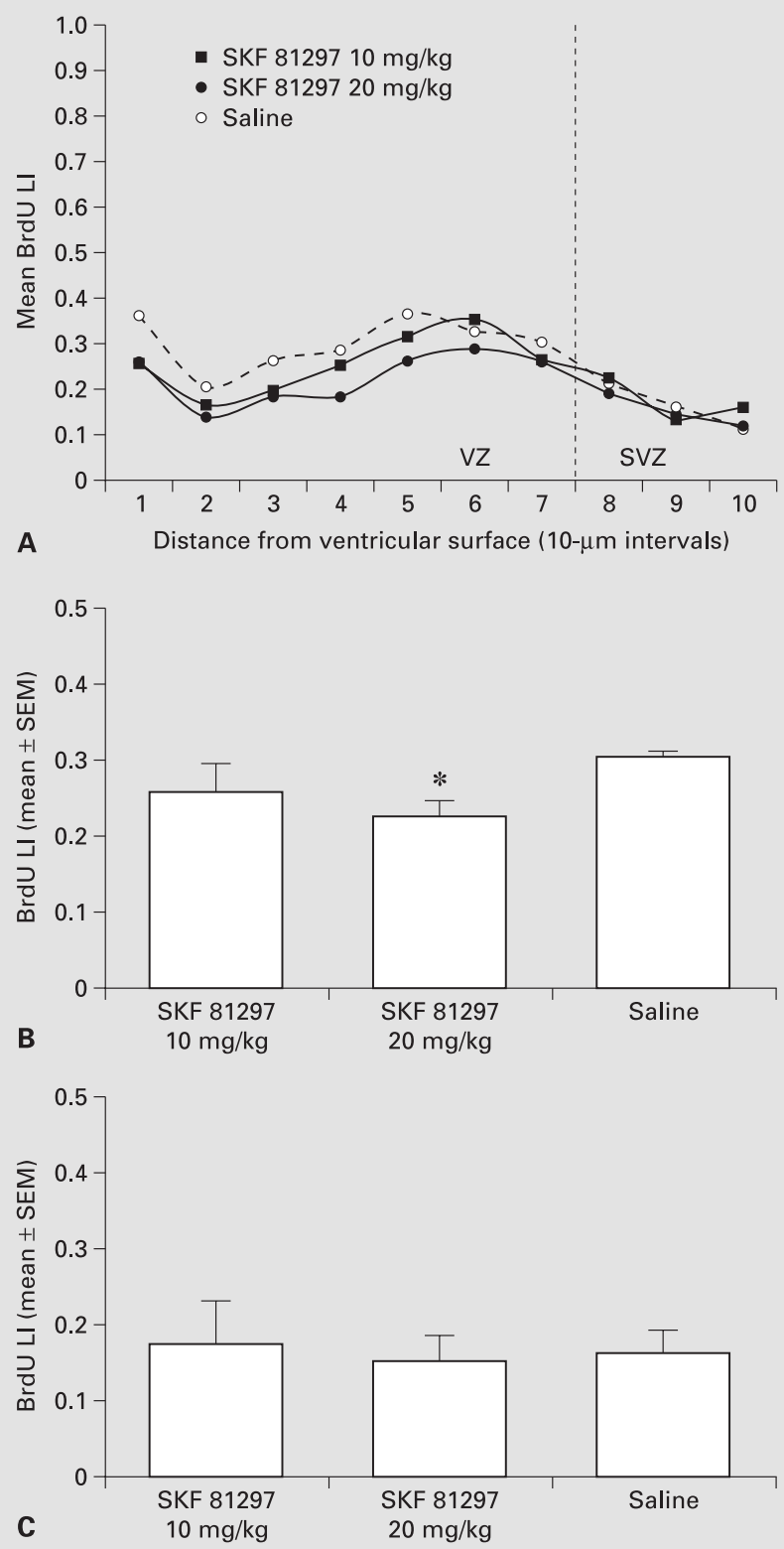

the PFC. Initially, the LI was calculated and plotted for each of the 10 'bins' (each bin was $10 \times 100 \mu \mathrm{m}$ in size) within a $100 \times 100 \mu \mathrm{m}$ sector of the proliferative zone (A). The highest LI was in bins 3-7 and in bin 1. Bins 3-7 represent the $\mathrm{S}$ phase zone, and bin 1 represents the zone (at the ventricular border) in which mitoses occur. As in the LGE (fig. 3A), the interkinetic nuclear migration was preserved following the drug administration. The LI is the lowest in the $20 \mathrm{mg} / \mathrm{kg}$ SKF 81297 group compared to the other groups in nearly every bin. The proliferative zone was partitioned into a VZ and SVZ, respectively, based on the distribution of BrdU-labeled nuclei. The LI was decreased in the $20 \mathrm{mg} / \mathrm{kg}$ SKF 81297 group compared to the saline group in the VZ (B). ${ }^{*} \mathrm{p}<0.005$. The LI in the $10 \mathrm{mg} / \mathrm{kg} \mathrm{SKF}$ 81297 group was not significantly different from that in the saline or the $20 \mathrm{mg} / \mathrm{kg}$ groups. There were no statistically significant differences between the groups in the SVZ $(\mathbf{C})$. 
Effects of Dopamine, $D_{1^{-}}$and $D_{2}$-Like Receptor Activation on BrdU LI in vivo

We examined the effects of activation of $\mathrm{D}_{1}$-like receptors on the BrdU LI by administering the $\mathrm{D}_{1}$-like receptor agonist SKF 81297 to dams carrying E15 mice. When the BrdU LI was plotted as a function of distance from the lateral ventricular border (i.e. for each 'bin'), we found that the interkinetic nuclear migration, a hallmark of pseudostratified proliferative epithelia [Boulder Committee, 1970], was preserved in the embryos exposed to saline and SKF 81297 in the LGE (fig. 3A) and the PFC (fig. 4A). Thus, the BrdU LI was higher in bins representing the $S$ phase zone (bins 3-7; fig. 3A and $4 A$ ), where nuclei of the bipolar neuroepithelial cells migrate for the DNA synthetic phase of the cell cycle and incorporate BrdU [Nowakowski et al., 1989; Takahashi et al., 1992]. The LI was also high at the ventricular border (bin 1) in the PFC (fig. 4A). Nuclei that were in $\mathrm{S}$ phase at the time of the BrdU injection enter the $G_{2}$ phase and migrate to the ventricular surface for the $\mathrm{M}$ phase over the 2.0-hour BrdU labeling period causing the increase in the BrdU LI in bin 1 [Takahashi et al., 1992, 1993; Bhide, 1996]. Thus, the nuclei that migrate between the $S$ phase zone and the ventricular border during $\mathrm{S}$ and $\mathrm{M}$ phases belong to cells in the pseudostratified ventricular epithelium of the VZ [Takahashi et al., 1992, 1993; Bhide, 1996; Sheth and Bhide, 1997; Ohtani et al., 2003]. Nuclei of cells in the SVZ do not undergo interkinetic nuclear migration [Boulder Committee, 1970; Takahashi et al., 1992, 1993] and remain at or near the $S$ phase zone for all the cell cycle phases. The interkinetic nuclear migratory pattern is the basis for distinguishing between VZ and SVZ progenitors in the 2.0-hour BrdU labeling paradigm. The increase in the BrdU LI in bin 1 occurred in the PFC but not in the LGE (compare fig. $3 \mathrm{~A}$ and $4 \mathrm{~A}$ ). This result is to be expected, as the relative size of the pseudostratified ventricular epithelium or the VZ is considerably smaller than the SVZ in the LGE [Bhide, 1996; Sheth and Bhide, 1997]. Therefore, relatively few BrdU-labeled precursor cells would be expected to migrate to bin 1 in the LGE over the 2.0-hour survival period compared to the PFC.

Overall, exposure to SKF 81297 did not perturb the interkinetic nuclear migration, indicating that the $\mathrm{D}_{1}$-like agonist did not produce toxic or other harmful effects to arrest cells in specific cell cycle phases and that passage through the different cell cycle checkpoints was not blocked. SKF 81297 reduced the BrdU LI in every bin in the LGE and the PFC. This extent of reduction was evident at the lower dose $(10 \mathrm{mg} / \mathrm{kg})$ in the LGE and only at the higher dose $(20 \mathrm{mg} / \mathrm{kg})$ in the PFC (fig. 3A and 4A).
We calculated the BrdU LI separately for the VZ and the SVZ and found that SKF 81297 reduced the BrdU LI both in the VZ and the SVZ in the LGE (fig. 3B, C) and only in the VZ in the PFC (fig. 4B, C). Once again the reduction in the $\mathrm{VZ}$ of the $\mathrm{PFC}$ was evident only at the higher dose $(20 \mathrm{mg} / \mathrm{kg})$.

We calculated the 2.0-hour BrdU LI in the PFC and LGE after injection of dopamine or ascorbic acid directly into the lateral ventricles of E15 mice. Dopamine reduced the LI in the VZ and the SVZ of the LGE (fig. 5A, B) and in the VZ, but not the SVZ of the PFC (fig. 5C, D).

In separate experiments, the $\mathrm{D}_{1}$-like receptor antagonist Schering 23390 or saline was injected into the lateral ventricles, and the BrdU LI was calculated. The goals of these experiments were to block $\mathrm{D}_{1}$-like receptor activation and reveal the effects of $\mathrm{D}_{2}$-like receptor activation by endogenous dopamine. Our previous study showed that the density of $\mathrm{D}_{2}$-like binding sites was remarkably lower than that of $\mathrm{D}_{1}$-like binding sites in the E15 telencephalon [Ohtani et al., 2003]. Therefore, we did not inject a $\mathrm{D}_{2}$-like agonist into the ventricles, as activation of the $\mathrm{D}_{2}$-like receptors by the exogenous $\mathrm{D}_{2}$-like agonist might not be sufficient to override the effects of activation of the abundant $\mathrm{D}_{1}$-like receptors by the endogenous dopamine rendering a negative outcome essentially uninformative. We found that Schering 23390 injection increased the BrdU LI in both the VZ and the SVZ of the LGE (fig. 5E, F) and only in the SVZ of the PFC (fig. 5G, $\mathrm{H})$.

In both the sets of experiments described above using the in utero intraventricular injection method, we found that the interkinetic nuclear migration was preserved in the LGE and the PFC. When the BrdU LI was plotted against distance from the ventricular border, the plots resembled those for the SKF 81297 or saline injection experiments (fig. $3 \mathrm{~A}$ and $4 \mathrm{~A}$ ), and the changes in the BrdU LI mentioned above occurred in virtually every bin. For the sake of brevity, we have not illustrated these data.

\section{Effects of Dopamine, $D_{1^{-}}$and $D_{2}$-Like Receptor} Activation in Dissociated Neostriatal Cell Cultures

We exposed the cultures to dopamine, its receptor agonists or antagonists and BrdU for $12 \mathrm{~h}$ and fixed the cultures $12 \mathrm{~h}$ later. We found that the $\mathrm{D}_{1}$-like receptor agonist SKF $81297(10 \mu M)$ reduced the BrdU LI whereas the $\mathrm{D}_{2}$-like agonist quinpirole hydrochloride $(1$ or $10 \mu M)$ did not produce significant changes (fig. 6A). Dopamine $(5 \mu M)$ also reduced the BrdU LI (fig. 6B). When the cultures were exposed to the $\mathrm{D}_{1}$-like receptor antagonist 

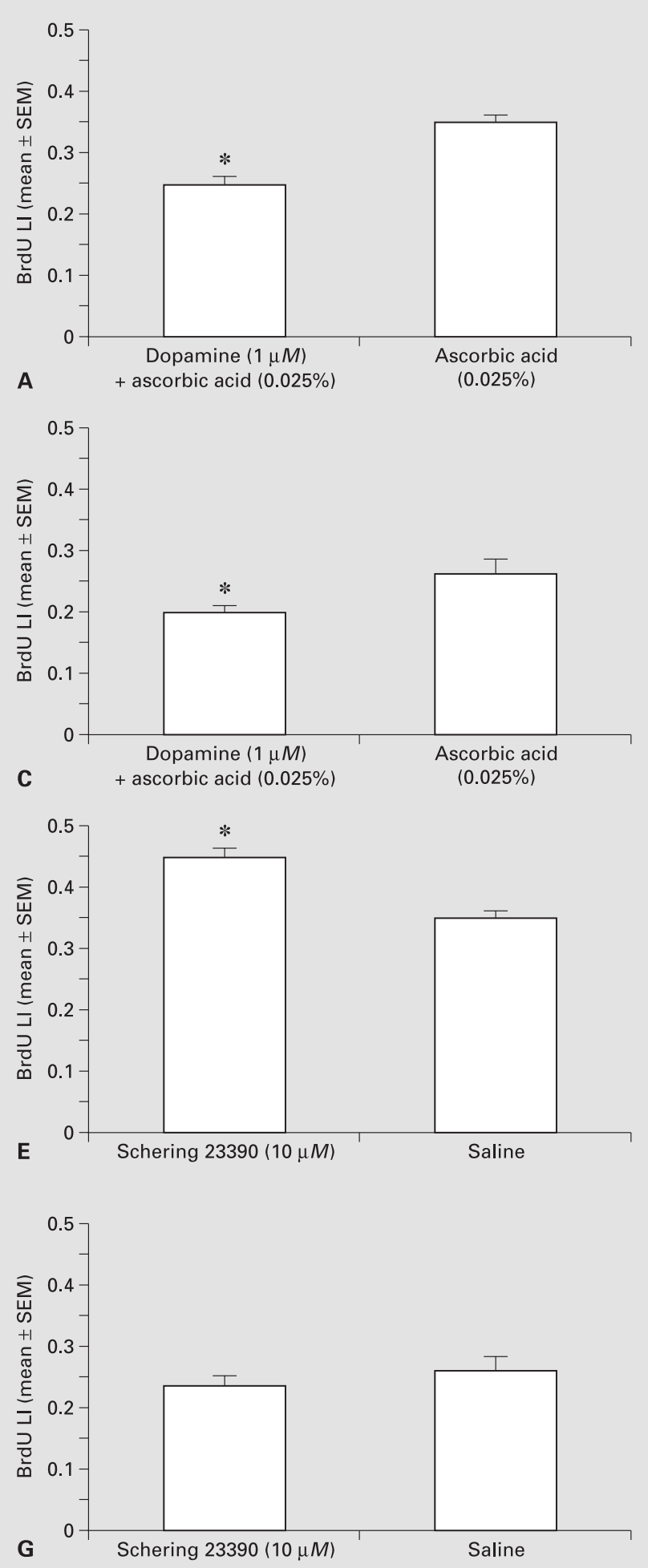

Fig. 5. The effects of in utero intraventricular administrations of dopamine (A-D) or the $\mathrm{D}_{1}$-like receptor antagonist Schering 23390 (E-H) on BrdU LI in the LGE and the PFC. Dopamine reduced the BrdU LI in the VZ and the SVZ of the LGE (A, B) and only in the VZ of the PFC (C, D). Dopamine was dissolved in PBS containing
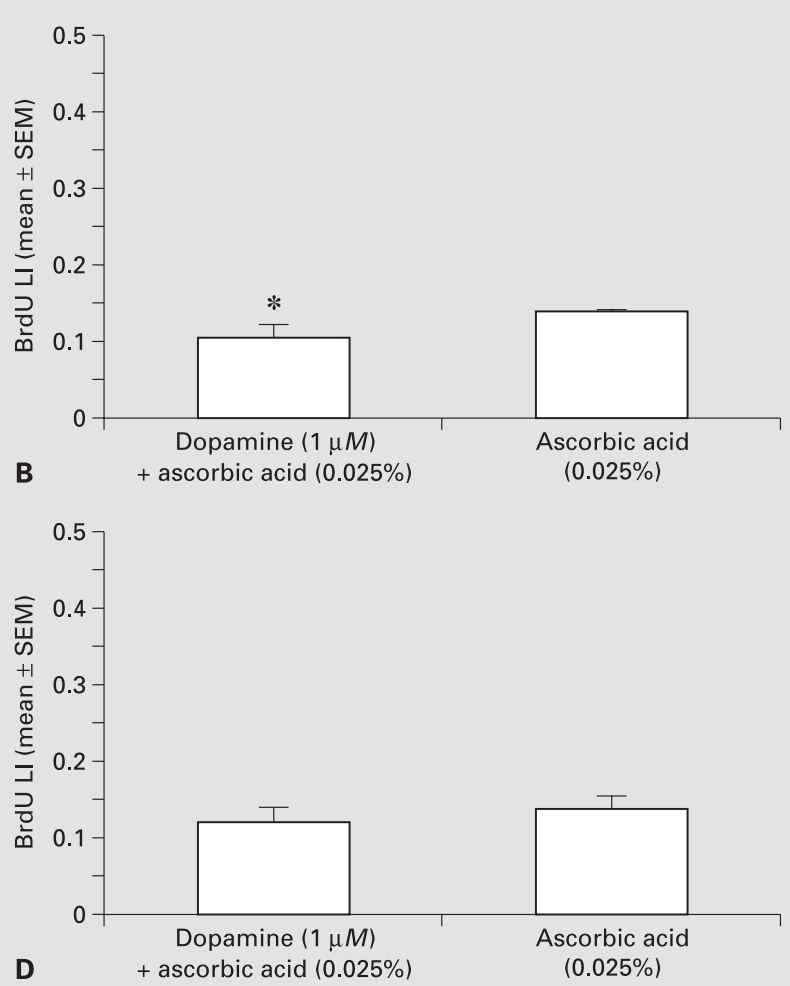

D
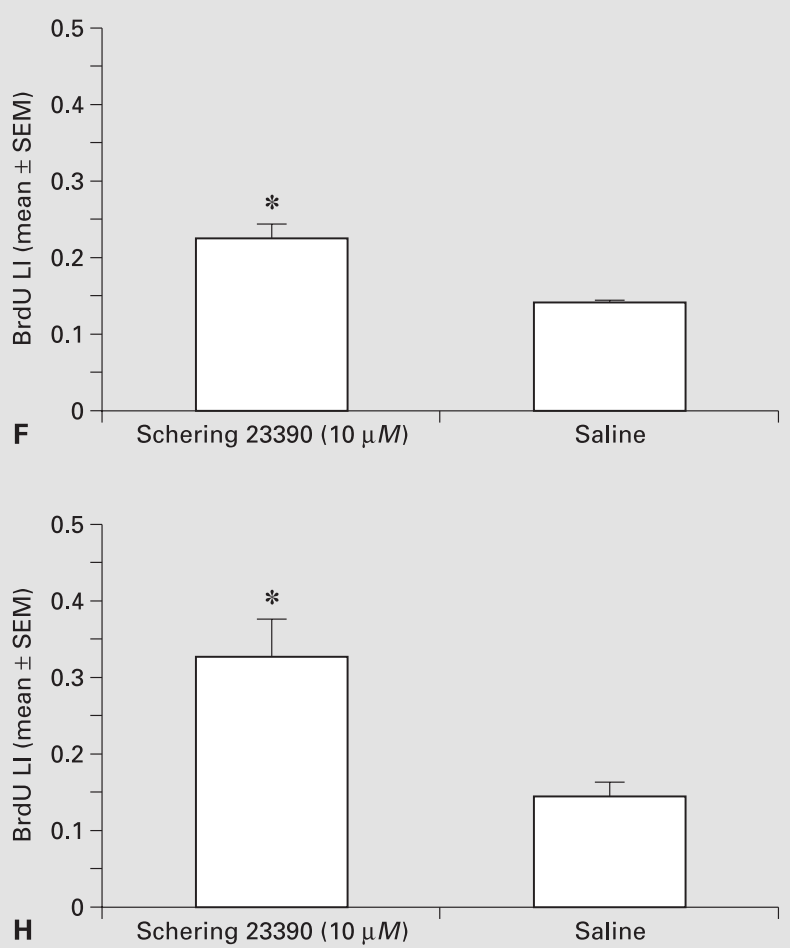

$0.025 \%$ ascorbic acid, which retards oxidation of dopamine. Following in utero intraventricular administration of Schering 23390, the BrdU LI was significantly increased in the VZ and the SVZ of the $\operatorname{LGE}(\mathbf{E}, \mathbf{F})$ and in the SVZ of the PFC (H); there were no statistically significant differences in the $\mathrm{VZ}$ of the $\operatorname{PFC}(\mathbf{G}) .{ }^{*} \mathrm{p}<0.02$.

Dev Neurosci 2004;26:229-244 

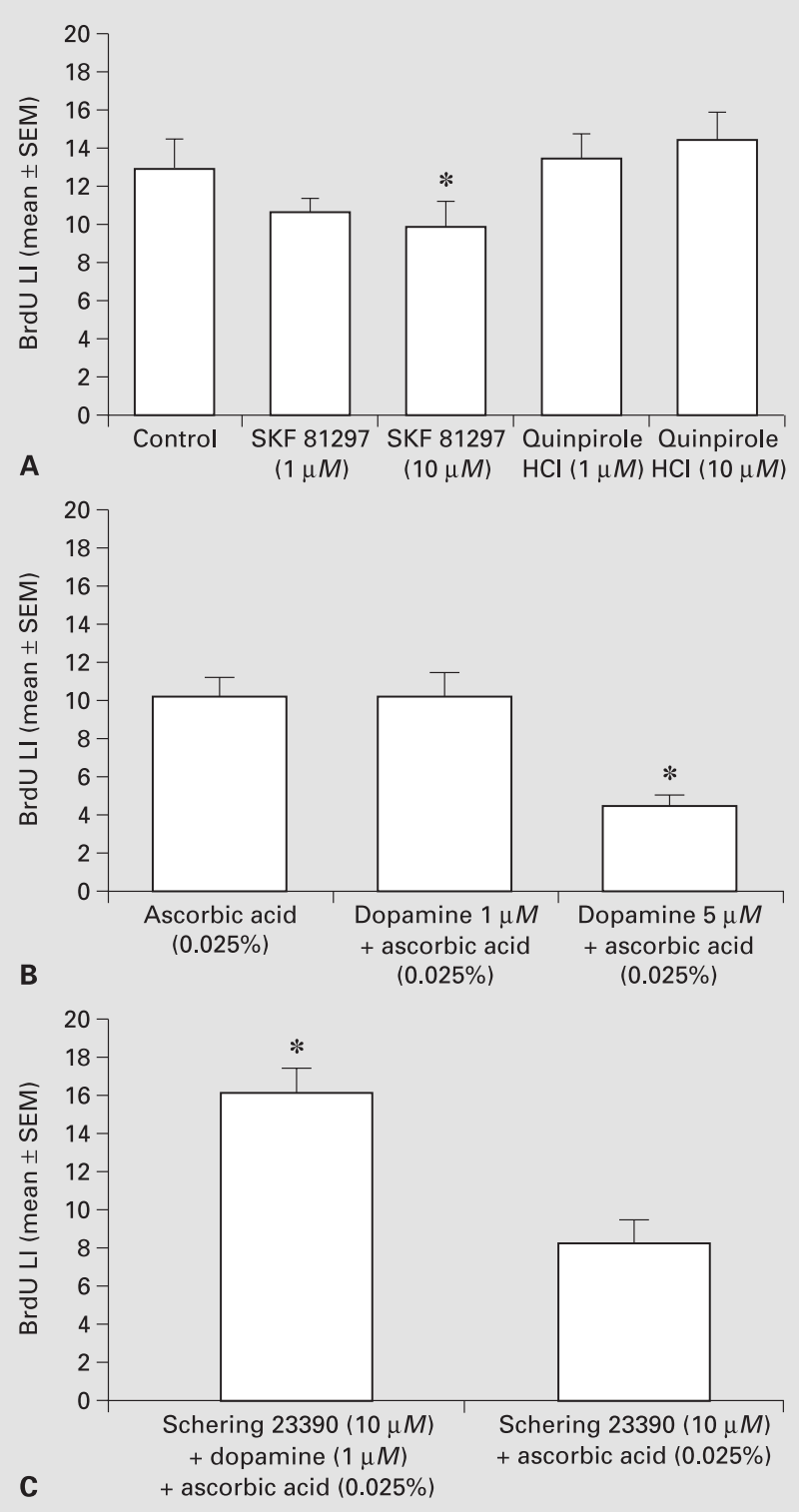

Fig. 6. The effects of dopamine and its receptor agonists on BrdU LI in cultures of dissociated neostriatal cells maintained for $24 \mathrm{~h}$. The $\mathrm{D}_{1}$-like agonist SKF 81297 reduced the BrdU LI (at $10 \mu M$ concentration and not at $1 \mu M ; \mathbf{A})$. The $\mathrm{D}_{2}$-like agonist quinpirole hydrochloride did not produce significant changes $(\mathbf{A})$. Dopamine reduced the BrdU LI at a concentration of $5 \mu M(\mathbf{B})$. When the $\mathrm{D}_{1}$-like receptors were blocked with Schering 23390 (C) beginning $2 \mathrm{~h}$ prior to the addition of dopamine to the cultures, the BrdU LI was increased. $* \mathrm{p}<0.05$.

Fig. 7. The effects of dopamine receptor agonists on progenitor cell proliferation and differentiation in cultures of dissociated neostriatal cells. The $\mathrm{D}_{1}$-like agonist SKF 81297 reduced the PCNA LI, and the $\mathrm{D}_{2}$-like agonist quinpirole hydrochloride increased it (A) following $24 \mathrm{~h}$ in culture, confirming the antimitogenic and mitogenic effects of $\mathrm{D}_{1}$-like and $\mathrm{D}_{2}$-like receptor activation. Quinpirole hydrochloride increased the relative proportion of A2B5-positive, presumptive glial precursor cells whereas SKF 81297 did not produce significant

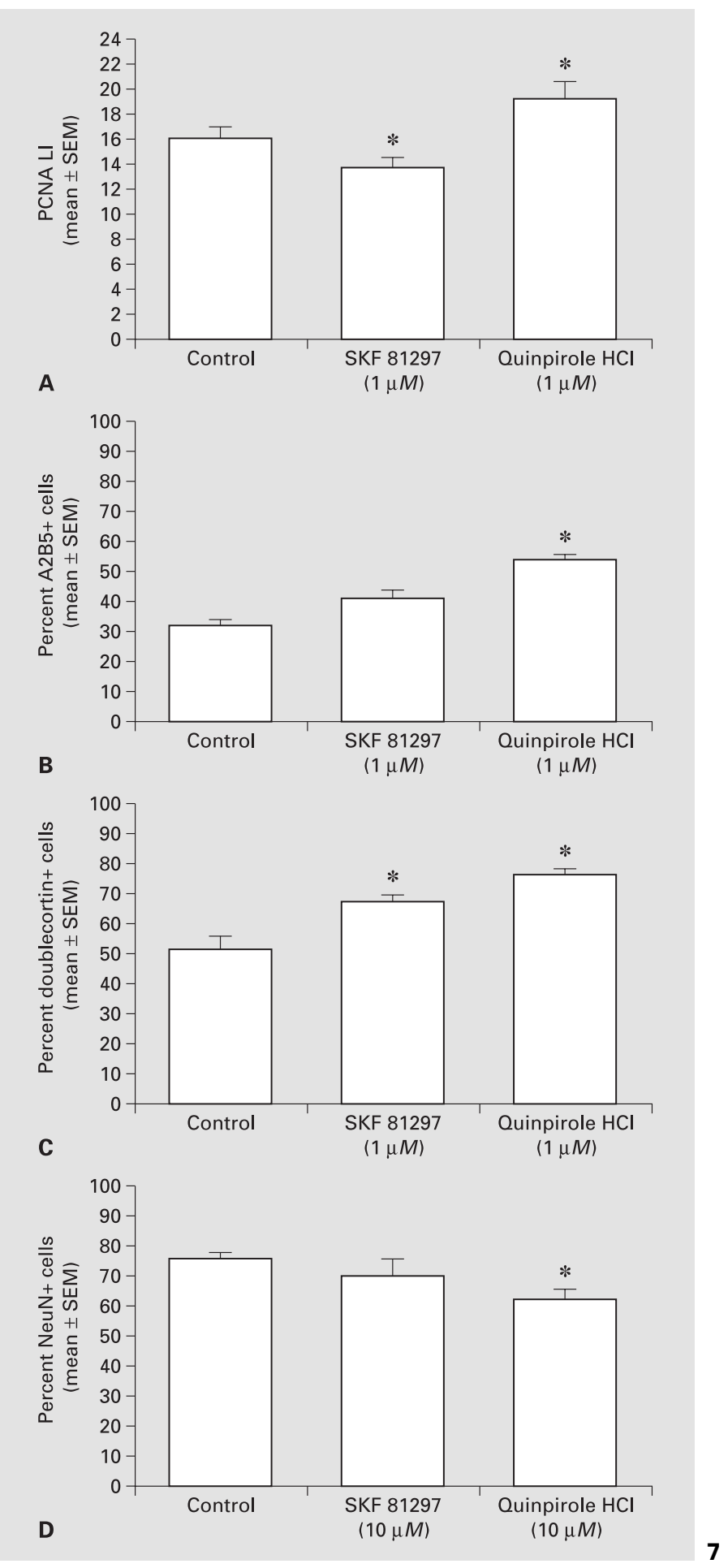

changes following $24 \mathrm{~h}$ in culture (B). Both SKF 81297 and quinpirole hydrochloride increased the relative numbers of doublecortinpositive immature neurons following $24 \mathrm{~h}$ in culture (C). Following 5 days in culture, the $\mathrm{D}_{2}$-like agonist quinpirole hydrochloride decreased the relative numbers of NeuN-positive cells (D) whereas the $\mathrm{D}_{1}$-like agonist SKF 81297 did not produce significant changes. $* \mathrm{p}<$ 0.025 . 
Schering 23390 and then to dopamine, the BrdU LI was increased (fig. 6C). In other experiments, we used PCNA immunohistochemistry to label cells in $S, G_{2}$ and $M$ phases following exposure to $\mathrm{D}_{1}$-like and $\mathrm{D}_{2}$-like agonists. We found that the $\mathrm{D}_{1}$-like agonist SKF 81297 decreased the PCNA LI whereas the $\mathrm{D}_{2}$-like agonist quinpirole increased it (fig. 7A). The $\mathrm{D}_{2}$-like receptor agonist quinpirole hydrochloride increased the total number of cells per field (mean \pm SEM values: quinpirole hydrochloride $=$ $148.9 \pm 13.2$; control $=119.2 \pm 1.3$; $\mathrm{t}$ test, $\mathrm{p}=0.006)$, whereas the $\mathrm{D}_{1}$-like agonist SKF 81297 did not produce significant changes in this measurement (mean \pm SEM values: SKF 81297 = $116.8 \pm 6.7$; control = $119.2 \pm 1.3$; t test, $\mathrm{p}=0.75$ ).

In other experiments, we used immunohistochemistry for A2B5, a selective marker of glial precursor cells [Raff, 1989; Fok-Seang and Miller, 1994; Rao and Mayer-Proschel, 1997; Dietrich et al., 2002], to determine if the $\mathrm{D}_{1^{-}}$ like and $\mathrm{D}_{2}$-like agonists selectively affected glial precursor cells. We found that the $\mathrm{D}_{2}$-like agonist quinpirole hydrochloride increased the A2B5 LI whereas the $\mathrm{D}_{1}$-like agonist SKF 81297 did not produce significant changes (fig. 7B).

We examined the effects of $\mathrm{D}_{1}$-like and $\mathrm{D}_{2}$-like receptor activation on the phenotype of cells produced. We used immunohistochemistry for doublecortin, a marker of postmitotic, immature neurons [Gleeson et al., 1998, 1999]. We found that both the $\mathrm{D}_{1}$-like and $\mathrm{D}_{2}$-like agonists increased the proportion of doublecortin-positive cells (fig. 7C).

Next, we examined the effects of $\mathrm{D}_{1}$-like and $\mathrm{D}_{2}$-like receptor activation on the relative proportion of mature neurons. For these experiments, we used cultures maintained for 5 days, as mature neuronal markers such as $\mathrm{NeuN}$ are not expressed in the short-term cultures (i.e. $24 \mathrm{~h}$ ) that we used for the other analyses. We found that $\mathrm{D}_{2}$-like receptor activation reduced the proportion of NeuN-positive cells whereas $D_{1}$-like receptor activation did not produce significant changes (fig. 7D). Neither the $\mathrm{D}_{1}$-like receptor agonist SKF 81297 nor the $\mathrm{D}_{2}$-like receptor agonist quinpirole hydrochloride produced significant changes in the relative proportion of GFAP-positive cells (mean \pm SEM values: control = $5.0 \pm 1.4$; SKF $81297=4.0$ \pm 0.6 ; quinpirole hydrochloride $=2.7 \pm 0.4$ ). The total number of cells per field was reduced in the cultures exposed to the $\mathrm{D}_{1}$-like agonist SKF 81297 whereas the $\mathrm{D}_{2-}$ like agonist quinpirole hydrochloride did not produce significant changes (mean \pm SEM values: control $=232.4 \pm$ 19.1; SKF 81297 = $174.6 \pm 19.0$; quinpirole hydrochloride $=189.7 \pm 18.3 ;$ SKF 81297 vs. control $\mathrm{p}<0.05$, t test $)$.
We calculated the relative proportion of pyknotic profiles based on bisbenzimide staining in each type of culture. The incidence of pyknotic profiles was $8-12 \%$ and did not show statistically significant differences among control or the different drug treatment conditions in short-term or long-term cultures.

\section{Discussion}

Our data show that dopamine can influence progenitor cell proliferation and differentiation in the embryonic mouse telencephalon. The data are summarized in tables 1 and 2. Presumptive dopaminergic axons enter the neuroepithelium and are in close proximity to dividing progenitor cells suggesting that LGE and PFC progenitors are exposed to dopamine. Dopamine's effects are mediated via $\mathrm{D}_{1}$-like and $\mathrm{D}_{2}$-like receptors, and activation of each type of receptor produces distinct, often opposing effects. Progenitor cells in the neostriatum and the PFC respond to dopamine receptor activation to different degrees, with the neostriatal progenitors being more responsive. The VZ progenitors appear to respond predominantly to $\mathrm{D}_{1}$-like receptor activation and the SVZ progenitors to $\mathrm{D}_{2}$-like receptor activation in the PFC. Moreover, $\mathrm{D}_{2}$-like receptor activation increases presumptive glial precursor cell numbers and decreases the relative proportion of NeuN-positive cells in dissociated neostriatal cell cultures. The data corroborate our previous findings on dopamine's effects on cell proliferation in the LGE at an earlier developmental stage (E13) and, more significantly, provide new information on dopamine's role in proliferation of precursor cells in the VZ and SVZ of the PFC and on precursor cell heterogeneity (i.e. neuronal vs. glial precursors) and differentiation in the neostriatum.

We employed in vivo and in vitro methods in the present study. The two experimental approaches complement each other, as they offer valuable insights not achievable by either approach alone. For example, we could partition the neuroepithelium into a VZ and SVZ in the intact brain and analyze dopamine's effects on the two progenitor populations separately. Such analyses are not feasible in dissociated cell cultures. The dissociated cell culture system is an effective tool to analyze the effects of dopamine receptor activation on progenitor cell diversity and phenotype of daughter cells, as the concentration of the drugs and period of exposure to the drugs could be controlled more effectively in short-term and long-term cultures. We used dissociated neostriatal rather than cortical cells in our in vitro experiments, as both the $\mathrm{VZ}$ and 
Table 1. A summary of the effects of dopamine and its receptor activation on BrdU LI in vivo

\begin{tabular}{|c|c|c|c|c|}
\hline & \multicolumn{2}{|l|}{ LGE } & \multicolumn{2}{|l|}{ PFC } \\
\hline & $\mathrm{VZ}$ & SVZ & $\mathrm{VZ}$ & SVZ \\
\hline $\mathrm{D}_{1}$-like receptor activation & Decrease $^{a}$ & Decrease $^{\mathrm{a}}$ & Decrease $^{b}$ & No change \\
\hline Dopamine & Decrease & Decrease & Decrease & No change \\
\hline $\mathrm{D}_{2}$-like receptor activation ${ }^{\mathrm{d}}$ & Increase & Increase & No change & Increase \\
\hline
\end{tabular}

The effective dose of the $\mathrm{D}_{1}$-like receptor agonist SKF 81297 was $10 \mathrm{mg} / \mathrm{kg}$.

The effective dose of the $\mathrm{D}_{1}$-like receptor agonist SKF 81297 was $20 \mathrm{mg} / \mathrm{kg}$.

No change at the dose of either 10 or $20 \mathrm{mg} / \mathrm{kg}$ of the $\mathrm{D}_{1}$-like receptor agonist SKF 81297.

d $\mathrm{D}_{1}$-like receptors were blocked with the specific antagonist Schering 23390 so that endogenous dopamine could activate only $\mathrm{D}_{2}$-like receptors.
Table 2. A summary of the effects of dopamine and its receptor activation on proliferation and differentiation of dissociated neostriatal cells

\begin{tabular}{|c|c|c|c|c|c|}
\hline & BrdU LI & PCNA LI & $\begin{array}{l}\text { A2B5+ } \\
\text { cells }\end{array}$ & $\begin{array}{l}\text { Doublecortin+ } \\
\text { cells }\end{array}$ & $\begin{array}{l}\text { NeuN+ } \\
\text { cells }{ }^{\mathrm{a}}\end{array}$ \\
\hline $\mathrm{D}_{1}$-like receptor activation & Decrease & Decrease & Decrease & Increase & No change \\
\hline Dopamine & Decrease & Decrease & & & n.a. \\
\hline $\mathrm{D}_{2}$-like receptor activation ${ }^{\mathrm{b}}$ & Increase & Increase & Increase & Increase & Decrease \\
\hline
\end{tabular}

n.a. $=$ Not assessed

a NeuN-positive cells were counted in cultures maintained for 5 days; all the other data are from cultures maintained for $24 \mathrm{~h}$.

b $\mathrm{D}_{1}$-like receptors were blocked with the specific antagonist Schering 23390, and dopamine was added to the medium so that it could activate only $\mathrm{D}_{2}$-like receptors.
SVZ progenitors in the $L G E$ responded to $\mathrm{D}_{1}$-like and $\mathrm{D}_{2}$ like receptor activation whereas only the $\mathrm{VZ}$ progenitors responded to $\mathrm{D}_{1}$-like receptor activation and only $\mathrm{SVZ}$ progenitors to $\mathrm{D}_{2}$-like receptor activation in the PFC. Therefore, we reasoned that neostriatal dissociated cells might show a more uniform response in vitro whereas the responses of cortical cells might be difficult to interpret. We point out that dissociated neostriatal cells contain not only LGE progenitors but also progenitors from the medial ganglionic eminence and caudal ganglionic eminence, which differ in their cell cycle kinetics [Bhide, 1996] and genetic profiles [Nery et al., 2002] from the LGE progenitors.

We used 2.0-hour and 12.0-hour BrdU labeling periods in the in vivo and in vitro experiments, respectively, for the analysis of cell proliferation. These BrdU exposure periods are similar to those used in our previous experiments [Ohtani et al., 2003; Crandall et al., 2004]. The 2.0hour BrdU LI in vivo is a reliable indicator of the relative proportion of progenitor cells in $\mathrm{S}, \mathrm{G}_{2}$ and $\mathrm{M}$ phases of the cell cycle. An increase in the 2.0-hour BrdU LI indicates an increase in the proportion of cells entering the $S$ phase from the $G_{1}$ phase, and a decrease in the LI indicates a decrease in S phase entry. The 12-hour BrdU exposure paradigm in the in vitro culture experiments also provides information about $\mathrm{G}_{1}$-to-S phase entry. However, in those experiments, BrdU-labeled cells likely represent cells in $\mathrm{S}$, $\mathrm{G}_{2}, \mathrm{M}$ and $\mathrm{G}_{1}$ phases of the cell cycle, and as in the in vivo experiments, the changes in the BrdU LI represent changes in $\mathrm{G}_{1}$-to-S phase entry.

Our choice of the $\mathrm{D}_{1}$-like and $\mathrm{D}_{2}$-like agonists was guided by our previously published data [Ohtani et al., 2003]. In those studies we used two $D_{1}$-like and two $D_{2-}$ like agonists and found that SKF 81297 and quinpirole hydrochloride produced more robust effects than the others on cell proliferation in the LGE [Ohtani et al., 2003]. Therefore, we used those two agonists in the present experiments. We had determined the most effective concentration ranges and performed studies of drug specificity using receptor antagonists for those two compounds [Ohtani et al., 2003]. Therefore, we did not perform detailed dose-response or specificity analyses again in the 


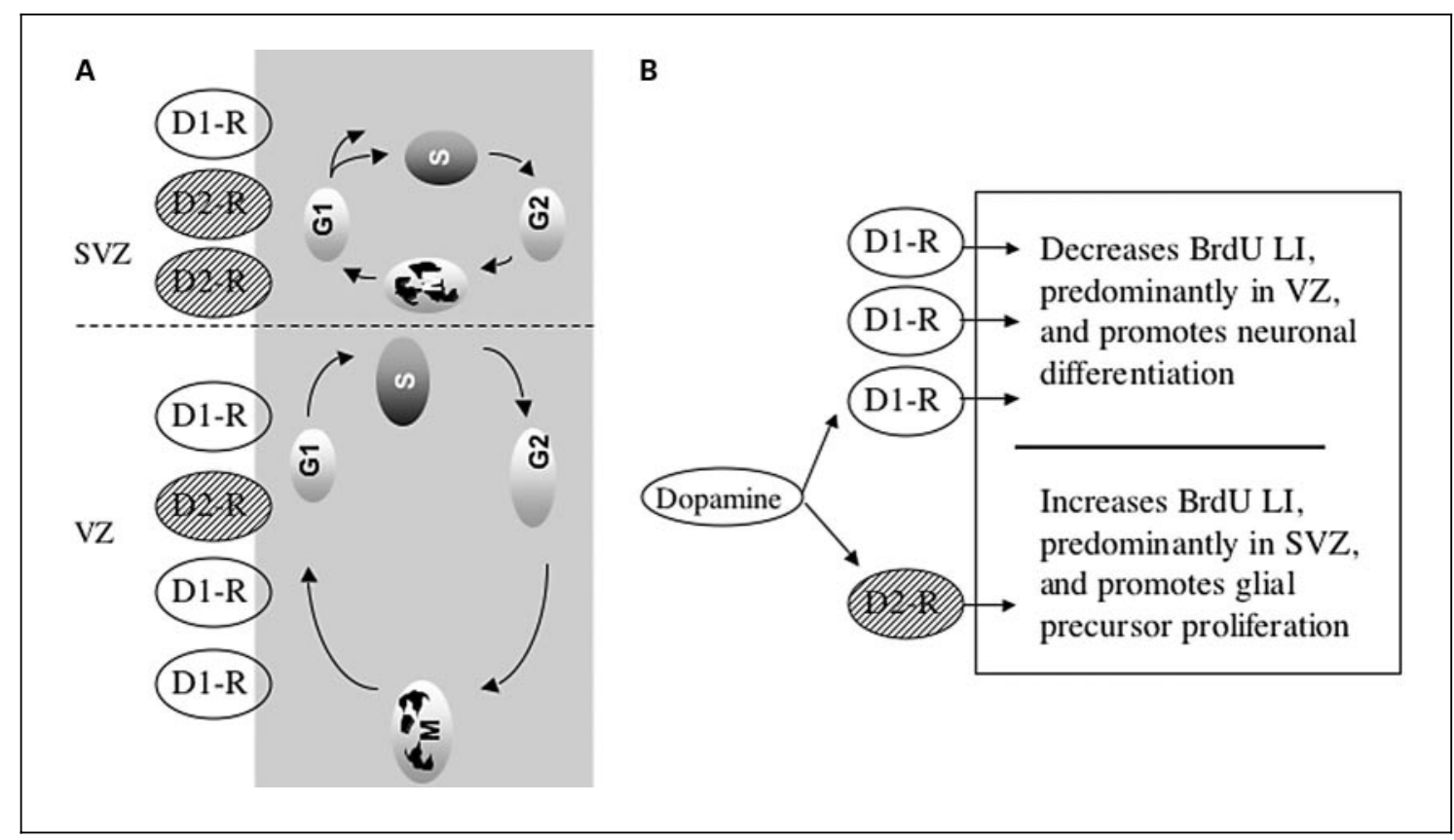

Fig. 8. Schematic representation of the distribution of $D_{1}$-like and $D_{2}$-like receptors $\left(D_{1}-R\right.$ and $D_{2}-R$, respectively) in the $V Z$ and $S V Z$ of the telencephalic neuroepithelium (A). The representation is deduced from data on changes in BrdU LI in the VZ and SVZ in response to specific receptor agonists and antagonists (tables 1 and 2). The VZ and SVZ are distinguished based on interkinetic nuclear migration patterns of the precursor cells. The VZ consists of a pseudostratified epithelium, in which the precursor cells undergo interkinetic nuclear migration $(\mathbf{A})$. Thus, nuclei of VZ precursor cells in the $S$ phase $(\mathrm{S})$ are positioned away from the ventricular surface (toward the bottom of the diagram), those of cells in the mitotic (M) phase at the ventricular surface and those of cells in the intervening gap phases $\left(G_{1}\right.$ and $\left.G_{2}\right)$ at intermediate positions. The $S V Z$ cells are intermingled with postmitotic cells in the intermediate zone, which lies adjacent to the VZ. SVZ cells do not form an epithelium (A). Since the reduction in BrdU LI produced by the $\mathrm{D}_{1}$-like agonist was more pronounced in the VZ than the SVZ [present data and Ohtani et al., 2003], we infer that $D_{1}-R$ binding sites predominate over $D_{2}-R$ sites in the VZ. Our data lead to the opposite inference concerning SVZ cells: predominance of $D_{2}-R$ binding sites over $D_{1}-R$ sites [present data and Ohtani et al., 2003]. A major conclusion from our study is that activation of $D_{1}-R$ and $D_{2}-R$ can produce opposing effects on proliferation and differentiation (B). Activation of $D_{1}-R$ decreases the BrdU LI (in vivo and in vitro) and increases the number of NeuN-positive, presumptive neurons (in vitro), whereas activation of $D_{2}-R$ increases the BrdU LI (in vivo and in vitro) and increases the A2B5-positive, presumptive glial precursor cell number (in vitro). In the embryonic neostriatum, $\mathrm{D}_{1}-\mathrm{R}$ binding sites predominate over the $\mathrm{D}_{2}-\mathrm{R}$ sites [Ohtani et al., 2003], accounting for the predominantly $\mathrm{D}_{1}$-like effects of dopamine in vivo and in vitro in the present and our earlier studies (B). Thus, our findings show that relative abundance of each receptor in a given cell type or a given brain region is a critical determinant of the net effects of dopamine on that cell type or in that region. present study. Our previous study also showed that SKF 81297 decreased the BrdU LI in the embryonic brain in a dose-dependent manner when administered to the dam intraperitoneally, indicating that it crossed the placental and fetal blood-brain barriers [Ohtani et al., 2003].

Our data summarized in figure 8 show that $\mathrm{D}_{1}$-like and $\mathrm{D}_{2}$-like receptor activation produced opposite effects on cell proliferation. In both the LGE and the PFC, $\mathrm{D}_{1}$-like receptor activation decreased the BrdU LI whereas $\mathrm{D}_{2-}$ like receptor activation increased it (table 1). The effects of dopamine on BrdU LI were $\mathrm{D}_{1}$-like effects, most likely due to the preponderance of $\mathrm{D}_{1}$-like binding sites in the embryonic telencephalon [Ohtani et al., 2003]. The reduction in the BrdU LI produced by dopamine and the $\mathrm{D}_{1}$-like agonist indicates that fewer cells entered the $\mathrm{S}$ phase (or a greater proportion of daughter cells exited the cell cycle) under these conditions. These effects are commonly termed as antimitogenic effects. The increase in the BrdU LI produced by the $\mathrm{D}_{2}$-like agonist indicates that a greater number of cells entered the $\mathrm{S}$ phase (or fewer daughter cells exited the cell cycle). These effects are commonly referred to as mitogenic effects. We used PCNA labeling to confirm independently the BrdU LI data, as both PCNA and the 2.0-hour BrdU exposure label cells in $\mathrm{S}, \mathrm{G}_{2}$ and $\mathrm{M}$ phases. 
The PCNA labeling data also indicated an antimitogenic effect of dopamine and the $\mathrm{D}_{1}$-like agonist and a mitogenic effect of the $\mathrm{D}_{2}$-like agonist. Although we did not calculate the number of cells exiting or re-entering the cycle under the influence of the two agonists directly, other data from our experiments suggest that dopamine and the $\mathrm{D}_{1}$-like agonist increased cell cycle exit and the $\mathrm{D}_{2}$-like agonist decreased it. For example, we found that in our dissociated cell cultures the $\mathrm{D}_{2}$-like agonist increased the total number of cells per field. This indicates that more cell divisions occurred (more cells entered the cycle) following exposure to the $\mathrm{D}_{2}$-like agonist. Similarly, the total number of cells was reduced in the 5-day cultures exposed to the $\mathrm{D}_{1}$-like agonist SKF 81297, suggesting that a greater number of cells exited the cell cycle under those conditions.

An interesting finding from the BrdU labeling data in vivo is that the progenitor cells in the LGE and the PFC respond to dopamine receptor activation to different degrees. The VZ and the SVZ progenitors both responded to the activation of $\mathrm{D}_{1}$-like and $\mathrm{D}_{2}$-like receptors in the LGE. However, in the PFC, $\mathrm{D}_{1}$-like receptor activation produced significant changes only in the $\mathrm{VZ}$ and $\mathrm{D}_{2}$-like receptor activation only in the SVZ (table 1). The LGE progenitors appear to be more responsive than the PFC progenitors to the effects of $\mathrm{D}_{1}$-like receptor activation. Thus, a lower dose of SKF $81297(10 \mathrm{mg} / \mathrm{kg})$ produced significant decreases in the BrdU LI in the LGE (fig. 3) whereas that dose had no effect in the PFC (fig. 4). A likely explanation for this difference is the higher density of dopamine receptor binding sites in the basal telencephalon compared to the dorsal telencephalon. We are in the process of acquiring such quantitative information. These findings highlight the regional differences in the telencephalon with respect to responsiveness of progenitor cells to dopamine receptor activation.

The data also showed that the SVZ progenitors respond to $\mathrm{D}_{2}$-like agonists to a greater degree than the $\mathrm{VZ}$ progenitors in the PFC. The relative abundance of $\mathrm{D}_{1^{-}}$and $\mathrm{D}_{2}$-like binding sites may be different in the $\mathrm{VZ}$ and the SVZ progenitor populations in the PFC. The VZ progenitors may have more $\mathrm{D}_{1}$-like binding sites and the $\mathrm{SVZ}$ progenitors may have more $\mathrm{D}_{2}$-like binding sites. Our previous data on LGE progenitors obtained from E13 mice suggested that the SVZ progenitors may be more responsive to $\mathrm{D}_{2}$-like receptor activation [Ohtani et al., 2003]. These observations led us to suggest a model (fig. 8A) that can explain differential effects of dopamine on precursor cell proliferation in the VZ versus the SVZ, based on differences in relative abundance of $D_{1}$-like and $D_{2}$-like receptor binding sites in the two proliferative zones.
We explored the possibility that dopamine receptor activation may alter the relative proportion of neuronal versus glial precursor cells or neuronal versus glial cells produced in our dissociated neostriatal cell cultures. We performed three sets of experiments to address the possibility. First, we counted the relative numbers of A2B5positive cells following exposure of the cultures to the $\mathrm{D}_{1^{-}}$ or $\mathrm{D}_{2}$-like receptor agonists. We found that the $\mathrm{D}_{1}$-like agonist SKF 81297 reduced and the $\mathrm{D}_{2}$-like agonist quinpirole hydrochloride increased the A2B5-positive cells. Thus, $\mathrm{D}_{2}$-like receptor activation promoted proliferation of presumptive glial precursor cells selectively or promoted proliferation of all precursor cells with enhancement in the ability of the cells to acquire an A2B5-positive phenotype. These data are consistent with the suggestion that VZ progenitors (believed to be neuronal precursors) are more responsive to $D_{1}$-like receptor activation and the SVZ progenitors (believed to be glial precursors) to $\mathrm{D}_{2-}$ like receptor activation. In the second set of experiments, we counted the relative numbers of immature neurons following exposure of the cultures to the $\mathrm{D}_{1}$ - or $\mathrm{D}_{2}$-like agonist. We found that activation of both the $\mathrm{D}_{1}$-like and $\mathrm{D}_{2}-$ like receptors promoted differentiation of doublecortinpositive, immature neurons. Thus, although $\mathrm{D}_{2}$-like receptor activation increased A2B5-positive presumptive glial precursor cells, it did not decrease the number of immature neurons. It is possible that the antimitogenic effects of the $\mathrm{D}_{1}$-like agonist SKF 81297 on presumptive neuronal precursors may be more robust than the mitogenic effects of the $\mathrm{D}_{2}$-like agonist quinpirole hydrochloride on presumptive glial precursors, perhaps due to the presence of a larger number of neuronal than glial precursors in our cultures. We performed a third set of experiments to explore this issue further. We maintained the cultures for a period of 5 days following an initial 12-hour exposure to the $\mathrm{D}_{1}$-like or $\mathrm{D}_{2}$-like agonists. The 5-day culture period was sufficient to permit immature neurons to differentiate into relatively mature NeuN-positive cells. In these cultures, the $\mathrm{D}_{2}$-like agonist quinpirole hydrochloride decreased the relative numbers of NeuN-positive cells. The $\mathrm{D}_{1}$-like agonist SKF 81297 did not produce significant changes. Neither the $\mathrm{D}_{1}$-like nor the $\mathrm{D}_{2}$-like agonist altered the relative proportion of GFAP-positive cells. When the BrdU LI data from the in vivo experiments and the A2B5 and NeuN labeling data from the cultures are taken together, it appears that $\mathrm{D}_{2}$-like receptor activation may promote the generation of nonneuronal cells. However, the $\mathrm{D}_{2}$-like agonist quinpirole hydrochloride did not produce an increase in GFAP-positive cells in the cultures. It is possible that the $\mathrm{D}_{2}$-like agonist 
increased oligodendrocyte cell numbers, which were not analyzed in the present study. In fact, previous reports suggested that $\mathrm{D}_{2}$-like receptor activation promoted proliferation of oligodendrocyte precursors [Bongarzone et al., 1998]. Another report suggested that the effects of $D_{1^{-}}$like receptor activation might also influence proliferation of specific subsets of cortical progenitor cells, identified based on responsiveness to specific growth factors [Zhang and Lidow, 2002]. These observations are summarized in figure $8 \mathrm{~B}$ to underscore the opposing effects of $\mathrm{D}_{1}$-like and $\mathrm{D}_{2}$-like receptor activation on cell proliferation and differentiation.

We recognize that the effects of $\mathrm{D}_{1}$-like and $\mathrm{D}_{2}$-like agonists on cell survival may confound the data from the 5-day cultures in the present study. Although we did not find differences in the incidence of pyknotic profiles as a result of the different drug treatments in our cultures, we cannot rule out the effects of the drugs on cell survival that may be independent of the effects on cell proliferation and differentiation. Therefore, although our data suggest that $\mathrm{D}_{2}$-like receptor activation may preferentially augment SVZ cell proliferation, A2B5-positive cell numbers and decrease NeuN-positive cell numbers, further analysis will be required to ascertain the role of dopamine receptor activation on neuronal versus glial cell differentiation in the telencephalon. Another confounding factor in the in vitro studies is that the dissociated cells are a mixture of progenitor cells from the LGE, medial ganglionic eminence and caudal ganglionic eminence. The different progenitors may respond to dopamine receptor activation differently, perhaps due to differences in the relative abundance of $\mathrm{D}_{1}$-like and $\mathrm{D}_{2}$-like binding sites, a possibility that we are investigating currently.

In summary, our data show that dopamine can influence proliferation and differentiation of precursor cells in the embryonic mouse telencephalon and that regional differences presumably caused by differences in the relative abundance of $\mathrm{D}_{1}$-like and $\mathrm{D}_{2}$-like receptor binding sites may regulate dopamine's overall effects (fig. 8). The presence of TH-positive axons in close proximity to proliferating progenitor cells and a direct demonstration of the effects of dopamine, rather than the effects of its receptor agonists alone, confer additional significance to the present data with regard to their relevance for understanding dopamine's role in mammalian brain development.

\section{Acknowledgements}

Supported by USPHS grants NS 43426, HD 05515, and a grant from the National Alliance for Autism Research. We are grateful to Igor Bagayev of the MGH Confocal Microscope Facility for his assistance and to Dr. James Crandall of the E.K. Shriver Center, University of Massachusetts Medical School, for his valuable comments on previous versions of the manuscript.

\section{References}

Anderson SA, Eisenstat DD, Shi L, Rubenstein JLR (1997): Interneuron migration from basal forebrain to neocortex: Dependence on $\mathrm{Dlx}$ genes. Science 278:474-476.

Bhide PG (1996): Cell cycle kinetics in the embryonic mouse corpus striatum. J Comp Neurol 374:506-522.

-Bongarzone ER, Howard SG, Schonmann V, Campagnoni AT (1998): Identification of the dopamine $D_{3}$ receptor in oligodendrocyte precursors: Potential role in regulating differentiation and myelin formation. J Neurosci 18:53445353.

Boulder Committee (1970): Embryonic vertebrate nervous system: Revised terminology. Anat Rec 166:257-262.

Cai L, Hayes NL, Nowakowski RS (1997): Local homogeneity of cell cycle length in developing mouse cortex. J Neurosci 17:2079-2087.

Crandall JE, Hackett HE, Tobet SA, Kosofsky BE, Bhide PG (2004): Cocaine exposure decreases GABA neuron migration from the ganglionic eminence to the cerebral cortex in embryonic mice. Cerebral Cortex 14:665-675.
Deacon TW, Pakzaban P, Isacson O (1994): The lateral ganglionic eminence is the origin of cells committed to striatal phenotypes: Neural transplantation and developmental evidence. Brain Res 668:211-219.

Demarque M, Represa A, Becq H, Khalilov I, BenAri Y, Aniksztejn L (2002): Paracrine intercellular communication by a $\mathrm{Ca}^{2+}$ - and SNAREindependent release of GABA and glutamate prior to synapse formation. Neuron 36:10511061.

Diaz J, Ridray S, Mignon V, Griffon N, Schwartz JC, Sokoloff P (1997): Selective expression of dopamine $\mathrm{D}_{3}$ receptor $\mathrm{mRNA}$ in proliferative zones during embryonic development of the rat brain. J Neurosci 17:4282-4292.

Dietrich J, Noble M, Mayer-Proschel M (2002): Characterization of A2B5+ glial precursor cells from cryopreserved human fetal brain progenitor cells. Glia 40:65-77.
Fok-Seang J, Miller RH (1994): Distribution and differentiation of A2B + glial precursors in the developing rat spinal cord. J Neurosci Res 37: 219-235.

Gleeson JG, Allen KM, Fox JW, Lamperti ED, Berkovic S, Scheffer I, Cooper EC, Dobyns WB, Minnerath SR, Ross ME, Walsh CA (1998): Doublecortin, a brain-specific gene mutated in human X-linked lissencephaly and double cortex syndrome, encodes a putative signaling protein. Cell 92:63-72.

Gleeson JG, Lin PT, Flanagan LA, Walsh CA (1999): Doublecortin is a microtubule-associated protein and is expressed widely by migrating neurons. Neuron 23:257-271.

- Haydar TF, Wang F, Schwartz ML, Rakic P (2000): Differential modulation of proliferation in the neocortical ventricular and subventricular zones. J Neurosci 20:5764-5774.

Hayes NL, Nowakowski RS (2000): Exploiting the dynamics of S-phase tracers in developing brain: Interkinetic nuclear migration for cells entering versus leaving the S phase. Dev Neurosci 22:44-55. 
Jung AB, Bennett JP Jr (1996): Development of striatal dopaminergic function. 1. Pre- and postnatal development of $m$ RNAs and binding sites for striatal $\mathrm{D}_{1}\left(\mathrm{D}_{1 \mathrm{a}}\right)$ and $\mathrm{D}_{2}\left(\mathrm{D}_{2 \mathrm{a}}\right)$ receptors. Dev Brain Res 94:109-120.

Kaufman MH (1992): The Atlas of Mouse Development, ed 2. New York, Academic Press.

Lauder JM (1988): Neurotransmitters as morphogens. Prog Brain Res 73:365-387.

Lauder JM (1993): Neurotransmitters as growth regulatory signals: Role of receptors and second messengers. Trends Neurosci 16:233-240.

- Lavdas AA, Blue ME, Lincoln J, Parnavelas JG (1997): Serotonin promotes the differentiation of glutamate neurons in organotypic slice cultures of the developing cerebral cortex. J Neurosci 17:7872-7880.

-Lavdas AA, Grigoriou M, Pachnis V, Parnavelas JG (1999): The medial ganglionic eminence gives rise to a population of early neurons in the developing cerebral cortex. J Neurosci 99: 7881-7888.

- Levitt P, Harvey JA, Friedman E, Simansky K, Murphy EH (1997): New evidence for neurotransmitter influences on brain development. Trends Neurosci 20:269-274.

LoTurco JJ, Owens DF, Heath MJS, Davis MBE Kriegstein AR (1995): GABA and glutamate depolarize cortical progenitor cells and inhibit DNA synthesis. Neuron 15:1287-1298.

Luk KC, Kennedy TE, Sadikot AF (2003): Glutamate promotes proliferation of striatal neuronal progenitors by an NMDA receptor-mediated mechanism. J Neurosci 23:2239-2250.

- Marien MR, Shin SH, Cooper GR, Jhamandas K (1984): Stability of dopamine in an in vitro incubation system using Medium 199. Can J Physiol Pharmacol 62:600-603.
Marin O, Anderson SA, Rubenstein JL (2000): Origin and molecular specification of striatal interneurons. J Neurosci 20:6063-6076.

Nery S, Fishell G, Corbin JG (2002): The caudal ganglionic eminence is a source of distinct cortical and subcortical cell populations. Nat Neurosci 5:1279-1287.

Nguyen L, Rigo JM, Rocher V, Belachew S, Malgrange B, Rogister B, Leprince P, Moonen G (2001): Neurotransmitters as early signals for central nervous system development. Cell Tissue Res 305:187-202.

Nowakowski RS, Lewin SB, Miller MW (1989): Bromodeoxyuridine immunohistochemical determination of the lengths of the cell cycle and the DNA-synthetic phases for an anatomically defined population. J Neurocytol 18:311-318.

Ohtani N, Goto T, Waeber C, Bhide PG (2003): Dopamine modulates cell cycle in the lateral ganglionic eminence. J Neurosci 23:28402850.

Popovik E, Haynes LW (2000): Survival and mitogenesis of neuroepithelial cells are influenced by noradrenergic but not cholinergic innervation in cultured embryonic rat neopallium. Brain Res 853:227-235.

Porter LL, Rizzo E, Hornung JP (1999): Dopamine affects parvalbumin expression during cortical development in vitro. J Neurosci 19:89909003.

Raff MC (1989): Glial cell diversification in the rat optic nerve. Science 243:1450-1455.

Rao MS, Mayer-Proschel M (1997): Glial-restricted precursors are derived from multipotent neuroepithelial stem cells. Dev Biol 188: 48-63.
Shearman LP, Zeitzer J, Weaver DR (1997): Widespread expression of functional $\mathrm{D}_{1}$-dopamine receptors in fetal rat brain. Dev Brain Res 102: 105-115.

Sheth AN, Bhide PG (1997): Concurrent cellular output from two proliferative populations in the early embryonic mouse corpus striatum. J Comp Neurol 383:220-230.

Stenman J, Toresson H, Campbell K (2003): Identification of two distinct progenitor populations in the lateral ganglionic eminence: Implications for striatal and olfactory bulb neurogenesis. J Neurosci 23:167-174.

Takahashi T, Nowakowski RS, Caviness VS Jr (1992): BUdR as an S-phase marker for quantitative studies of cytokinetic behaviour in the murine cerebral ventricular zone. J Neurocytol 21:185-197.

Takahashi T, Nowakowski RS, Caviness VS Jr (1993): Cell cycle parameters and patterns of nuclear movement in the neocortical proliferative zone of the fetal mouse. $\mathrm{J}$ Neurosci 13: 820-833.

Takahashi T, Nowakowski RS, Caviness VS Jr (1994): Mode of cell proliferation in the developing mouse neocortex. Proc Natl Acad Sci USA 91:375-379.

Theiler K (1972): The House Mouse: Development and Normal Stages from Fertilization to 4 Weeks of Age. Berlin, Springer.

Wichterle H, Turnbull DH, Nery S, Fishell G, Alvarez-Buylla A (2001): In utero fate mapping reveals distinct migratory pathways and fates of neurons born in the mammalian basal forebrain. Development 128:3759-3771.

Zhang L, Lidow MS (2002): $D_{1}$ dopamine receptor regulation of cell cycle in FGF- and EGF-supported primary cultures of embryonic cerebral cortical precursor cells. Int J Dev Neurosci 20: 593-606. 